149/4, 351-370., Budapest, 2019

\title{
Towards a high-resolution chronostratigraphy and geochronology for the Pannonian Stage: Significance of the Paks cores (Central Pannonian Basin)
}

\author{
MagYar, Imre ${ }^{1,2}$, Sztanó, Orsolya $^{3}$, Sebe, Krisztina ${ }^{4}$, Katona, Lajos $^{5}$, Csoma, Vivien ${ }^{3}$, Görög, Ágnes ${ }^{3}$, Tóth, Emőke ${ }^{3}$,

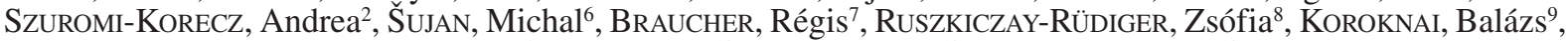 \\ Wórum, Géza ${ }^{9}$, SANT, Karin ${ }^{10}$, Kelder, Nick ${ }^{10}$, KrIJgSman, Wout $^{10}$

\begin{abstract}
${ }^{1}$ MTA-MTM-ELTE Research Group for Paleontology, Budapest; ${ }^{2}$ MOL Hungarian Oil and Gas Plc., Budapest; immagyar@ mol.hu; kaszuro@ mol.hu; ${ }^{3}$ Eötvös Loránd University, Budapest; sztano@caesar.elte.hu; csoma.vivien7@gmail.com; gorog@ludens.elte.hu; tothemoke.pal@ gmail.com; ${ }^{4}$ University of Pécs; krisztina.sebe@ gmail.com; ${ }^{5}$ Natural

History Museum of the Bakony Mts., Hungarian Natural History Museum, Zirc; finci@ nhmus.hu; ${ }^{6}$ Comenius University in Bratislava; miso@equis.sk; ${ }^{7}$ Aix-Marseille University, Aix-en-Provence; braucher@cerege.fr; ${ }^{8}$ Hungarian Academy of Sciences, Budapest; rrzsofi@ geochem.hu; ${ }^{9}$ Geomega Ltd., Budapest; koroknai@ geomega.hu; worg@ geomega.hu; ${ }^{10}$ Utrecht University; karin.sant@gmail.com; n.a.kelder@gmail.com; W.Krijgsman@uu.nl
\end{abstract}

\section{A paksi fúrómagok szerepe a pannóniai emelet nagy felbontású időrétegtanánakés geokronológiájának kifejlesztésében}

Összefoglalás

A pannóniai emelet kutatásában kivételes lehetőségként jelent meg, és kiemelkedő jelentőséggel bír a paksi atomerőmú bővítési folyamata során fúrt kőzetmagok sokoldalú rétegtani vizsgálata. A Paks II Atomerőmú Zrt. által 2015 és 2016 folyamán fúratott 6 magból 5 teljes (390 és 662 m közötti) vastagságban, folyamatos magmintavétellel harántolta a helybeli pannóniai képződményeket. A fúrások Paks környékén, egymástól 8-12 km távolságra mélyültek. Mindegyik fúrás a folyótorkolatoktól távol, nyílt és aránylag mély vízben képző́dött márgák (Endrôdi Formáció), a 200 méternél nem magasabb selfperemi lejtőn lerakódott homokos kőzetliszt (Algyői Formáció), és a delta előtéri kőzetlisztből, torkolati zátonyok homokjából, deltasíksági lignitből és homokos csatornakitöltésekből álló deltaképződmények (Újfalui Formáció) egymásutánját tárta fel. Két fúrómagból mágnesrétegtani, két másikból pedig autigén ${ }^{10} \mathrm{Be} /{ }^{9} \mathrm{Be}$ korhatározási módszerrel nyertünk korokat, majd a fúrások közötti szeizmikus korreláció megteremtésével kialakítottunk egy, a fúrómagok szedimentológiai és paleontológiai jellemzőitől független időrétegtani és geokronológiai keretet. A szarmatától kezdődő folyamatos üledékképződésnek és a legidősebb (11,6-9,1 millió éves) pannóniai rétegek összefüggó jelenlétének a bizonyítására további mikropaleontológiai vizsgálatokra lesz szükség, mert jelenleg sem a mágnesrétegtani, sem az autigén ${ }^{10} \mathrm{Be} /{ }^{9} \mathrm{Be}$ korhatározási módszer nem alkalmas a kondenzált mészmárga üledékek korolására. A 9,1 és 6,5 millió évek közötti intervallumot ezzel szemben változatos litológia és — sok esetben kivételesen jó megtartású — ősmaradványanyag képviseli a fúrómagokban. A delta üledékekben legalább 10 üledékes szekvenciát lehetett azonosítani és korrelálni; mivel ezek időtartama egyenként legfeljebb 200 ezer év lehetett, negyedrendú szekvenciáknak tekinthetôk. A fúrómagokban azonosított biozónák korhatárai igen jó egyezést mutatnak az eddig használt biokronosztratigráfiai rendszerrel, lényegében megerősítik és néhány helyen pontosítják azt. A paksi PAET fúrómagok eddig soha nem látott részletességú képet nyújtanak a Pannon-tó üledékes környezeteinek és élővilágának fejlődéséről a 9,1 és 6,5 millió év közötti intervallumban.

Kulcsszavak: Pannon-tó, rétegtan, kózetrétegtan, életrétegtan, szeizmikus rétegtan, szekvenciasztratigráfia, mágnesrétegtan, autigén ${ }^{10}$ Be^ Be kormeghatározás

Abstract

A new stratigraphic standard for the open lacustrine to deltaic Pannonian Stage is emerging from the combined sedimentological, lithostratigraphical, sequence stratigraphical, biostratigraphical, seismic stratigraphical, geochronological, and magnetostratigraphical investigations of 6 long drill cores. These were drilled by Paks II Nuclear Power Plant Plc. as a preparatory step for the construction of a new power plant near the city of Paks, Central Pannonian Basin, between 2015 and 2016. The boreholes are in a distance of 8-12 km from each other, and five of them fully penetrated the local Pannonian sequence in a thickness of 390 to $662 \mathrm{~m}$. Each core includes offshore clay marl deposited far from sediment entry points (Endrőd Fm), heterolithic, sandy siltstones of a $<200 \mathrm{~m}$ high shelf-margin slope (Algyő Fm), and several stacked deltaic deposits from prodelta silts to sandy mouth bars, heterolithics, lignite and sandy channel-fills of the delta plain (Újfalu Fm). Magnetostratigraphic investigations from two cores and authigenic ${ }^{10} \mathrm{Be} /{ }^{9} \mathrm{Be}$ dating from two others were combined by means of seismic correlation between the boreholes, and thus they provide a solid geochronological and chronostratigraphic basis for the interpretation of the sedimentological and palaeontological records of the cores. The continuous representation of the earliest Pannonian (11.6-9.1 Ma) in the cores needs further palaeontological investigation, as both magnetostratigraphy and authigenic ${ }^{10} \mathrm{Be} /{ }^{1} \mathrm{Be}$ dating failed to give reliable age data from the basal, condensed calcareous marls. The 9.1 to $6.5 \mathrm{Ma}$ interval, however, is represented in the cores by 
various lithologies and abundant and sometimes excellently preserved fossils. In the deltaic succession, 10 sedimentary sequences were correlated between the cores; as their duration is not more than $200 \mathrm{kyr}$ each, they can be regarded as $4^{\text {th }}$ order sequences. The palaeontological record of the cores shows a very good agreement with the formerly established biochronostratigraphical system. The cores provide an insight into the evolution of the sedimentary environment and the biota of Lake Pannon between 9.1 and 6.5 Ma with a so far unprecedented temporal and spatial resolution.

Keywords: Lake Pannon, stratigraphy, lithostratigraphy, biostratigraphy, seismic stratigraphy, sequence stratigraphy, magnetostratigraphy, authigenic ${ }^{10} \mathrm{Be} /{ }^{\ominus} \mathrm{Be}$ dating

\section{Introduction}

The chronostratigraphic subdivision, correlation, and dating of the lacustrine to fluvial Pannonian Stage (Upper Miocene-Pliocene, Pannonian Basin System, PBS) has always been a problematic issue (for a historical summary, see MAGYAR \& GEARY 2012). In the 1980s, a series of deep wells with continuous coring were drilled in Hungary with the purpose of improving the stratigraphy and geochronology of the late Neogene sedimentary sequence of the PBS (e.g. LANTOS et al. 1992, Elston et al. 1994). These cores were subject to detailed biostratigraphic and magnetostratigraphic investigations, and where present, the intercalated volcanic layers were dated with the K/Ar method. The resulting dataset provided a base for seismic correlations and sequence stratigraphic interpretations, which led to a completely new sedimentary and chronostratigraphic model of the Pannonian Stage (e.g. BÉRCZI 1988, PoGÁCSÁs et al. 1988, VAKARCS et al. 1994).

Although most of the inferences from these old cores are still considered valid, multiple stratigraphic problems remained and hinder precise correlation and reliable dating within the non-marine basin fill: 1) the fossil record of only a few cores was published (JÁMBOR et al. 1985, KORPÁsHóDI 1992, SÜTŐ-SzENTAI 2000), and biostratigraphic subdivision of the upper part of the Neogene (between ca 8-2.6 Ma) remained lacking (MAGYAR \& GEARY 2012); 2) serious doubts emerged concerning the reliability of magnetic polarity measurements and magnetostratigraphic interpretations because the main magnetic carrier in the cores was the diagenetically formed greigite (BABINSZKI et al. 2007); 3 ) the K/Ar dating often gave contradictory results and the uncertainty of the measurements was usually very high (e.g. BALÁZs \& NuSSZER 1987, MAGYAR et al. 1999); 4) seismic correlations were not always compatible with the biostratigraphic and geochronological data from the cores (e.g. TóTH-MAKK 2007); and 5) basin-wide correlation of thirdorder sequence boundaries remained ambiguous (cf. VAKARCS et al. 1994, SACCHI et al. 1999, TóTH-MAKK 2007), whereas higher order sequences are too small to correlate between small depressions (SzTANó et al. 2013a). As a consequence, dating of the late Neogene succession within the PBS could so far only be carried out with relatively high uncertainty (+/-0.5 Ma).

An unprecedented opportunity for testing and improving the currently used Pannonian biochronostratigraphic model arose when several-hundred-metres long Pannonian cores were drilled by Paks II Nuclear Power Plant Private Limited Company in 2015-2016 as a preparatory step for the con- struction of a new power plant near the city of Paks, central Pannonian Basin. The sedimentological and palaeontological analysis of the cores combined with magnetostratigraphic and authigenic ${ }^{10} \mathrm{Be} /{ }^{9} \mathrm{Be}$ dating and seismic correlations between the boreholes is resulting in a well-grounded, reliable, highresolution chronostratigraphy for the penetrated part of the Pannonian sequence. This work is not complete yet, but here we share the preliminary results as a tribute paid to our professor, colleague, and friend, Ferenc HoRvÁtH. As a member of the Scientific Advisory Board for this industrial Geological Research Program of Paks II Ltd., he was fully aware of the scientific potential and value of the cores. With the enthusiasm that was so characteristic to him, he actively supported our efforts to get access to the cores, to obtain permission for stratigraphic sampling, and to publish the results to the scientific community.

\section{Stratigraphic background}

At about the Middle-Late Miocene boundary (11.6 Ma), the PBS lost its connections to other marine Paratethyan basins, and the environment changed from restricted marine to Caspian-type brackish lacustrine with endemic aquatic biota. The several-km-thick Pannonian Stage, comprising the Upper Miocene and the Pliocene of the PBS, consists of deep water marls, turbiditic sandstones, slope shales, stacked deltaic deposits and fluvial sediments (JuHÁSZ 1992, SzTANó et al. 2013a, b). The boundary between the major lithostratigraphic units is diachronous, reflecting the gradual advance of sand-bearing depositional systems from the margins towards the basin center (HORVÁTH \& POGÁCSÁs 1988, JUHÁSZ 1994).

The combination of biostratigraphy, based on endemic molluscs, ostracods, and dinoflagellates retrieved from both surface outcrops and drilling cores, with seismic stratigraphy lead to a biochronostratigraphic system, which was tentatively calibrated against the geological time scale through radiometric age measurements and magnetostratigraphic studies (for a summary, see MAGYAR \& GEARY 2012). This dataset allowed the age calibration of the shelfedge slope advancing across the PBS (VAKARCS et al. 1994, MAGYAR et al. 2013).

The new studied cores, designated with the acronym "PAET" (from the Hungarian for "Paks nuclear power plant, plot designation") were drilled in the wide vicinity of Paks, a town located $100 \mathrm{~km}$ south of Budapest on the right bank of the Danube. The thickness of the Pannonian sequence is relatively small, only 400-800 $\mathrm{m}$ in this area, depending on 
the morphology of the highly complex Palaeo-Mesozoic basement and on the thickness of the Lower to Middle Miocene strata. Former stratigraphic data for the Pannonian of the region came from fully cored reference drillings of the 1970s-1990s, such as Lajoskomárom-1 (JÁMBOR et al. 1985), Tengelic-2 (HALMAI et al. 1982, KorPÁs-Hódi 1982, SÜTŐ-SZENTAI 1982, SzÉLES 1982), Kaskantyú-2 (Elston et al. 1994; JuHÁsz et al. 1996, 1997; LANTOS et al. 1992; MAgYAR et al. 1999; PoGÁCSÁs et al. 1994; Tóth-MAKK 2007), and Paks-2, -3, -4a, -4b, -4c (SzUROMI-KoRECZ 1992, SüTŐ-SzEnTAI 2000) (Figure 1). The lessons learnt from these old cores about the Pannonian stratigraphy of the region can be summarised as follows. 1) The deeper the base of the Pannonian Stage is, the older its basal layers are. In the local - still relatively shallow - depocenters, the oldest Pannonian biozones are usually condensed and thus difficult to identify. On the local highs, the younger Pannonian directly overlies the pre-Neogene basement with a significant hiatus, and the resulted base Pannonian unconformity is easily recognisable on seismic profiles. 2) The bulk of the Pannonian sequence (the uppermost 500-600 m) represents the youngest biozones of the Pannonian Stage (Spiniferites validus and Galeacysta etrusca Zones in the dinoflagellate zonation and Congeria rhomboidea and Prosodacnomya
Zones in the mollusc zonation), dated younger than ca $9 \mathrm{Ma}$ (MAGYAR \& GEARY 2012). 3) The prograding shelf-margin slope passed by the area roughly at 8.5-8.0 Ma ago (Magyar et al. 2013). 4) The Pannonian Stage is truncated by an erosional unconformity, separating the Upper Miocene from the overlying Pliocene and/or Pleistocene (MAgYaR \& SZTANÓ 2008).

\section{Materials and methods}

We have investigated 6 PAET cores; their location is indicated in Figures 1 and 2, and the basic data of their Pannonian intervals are summarised in Table $I$.

In each core, the facies, i.e. lithological variations, grain size, sedimentary structures and macrofossils, were logged from bottom to top with an accuracy of $10 \mathrm{~cm}$ and we interpreted the sedimentological features in terms of depositional processes and environments. Based on the shift of facies, sedimentary cycles (i.e. parasequences and parasequence sets) were determined, and their overall stacking pattern was used to cross-check correlations.

All interpretable mollusc remains were picked from the cores, and a large part of them is cleaned and determined by

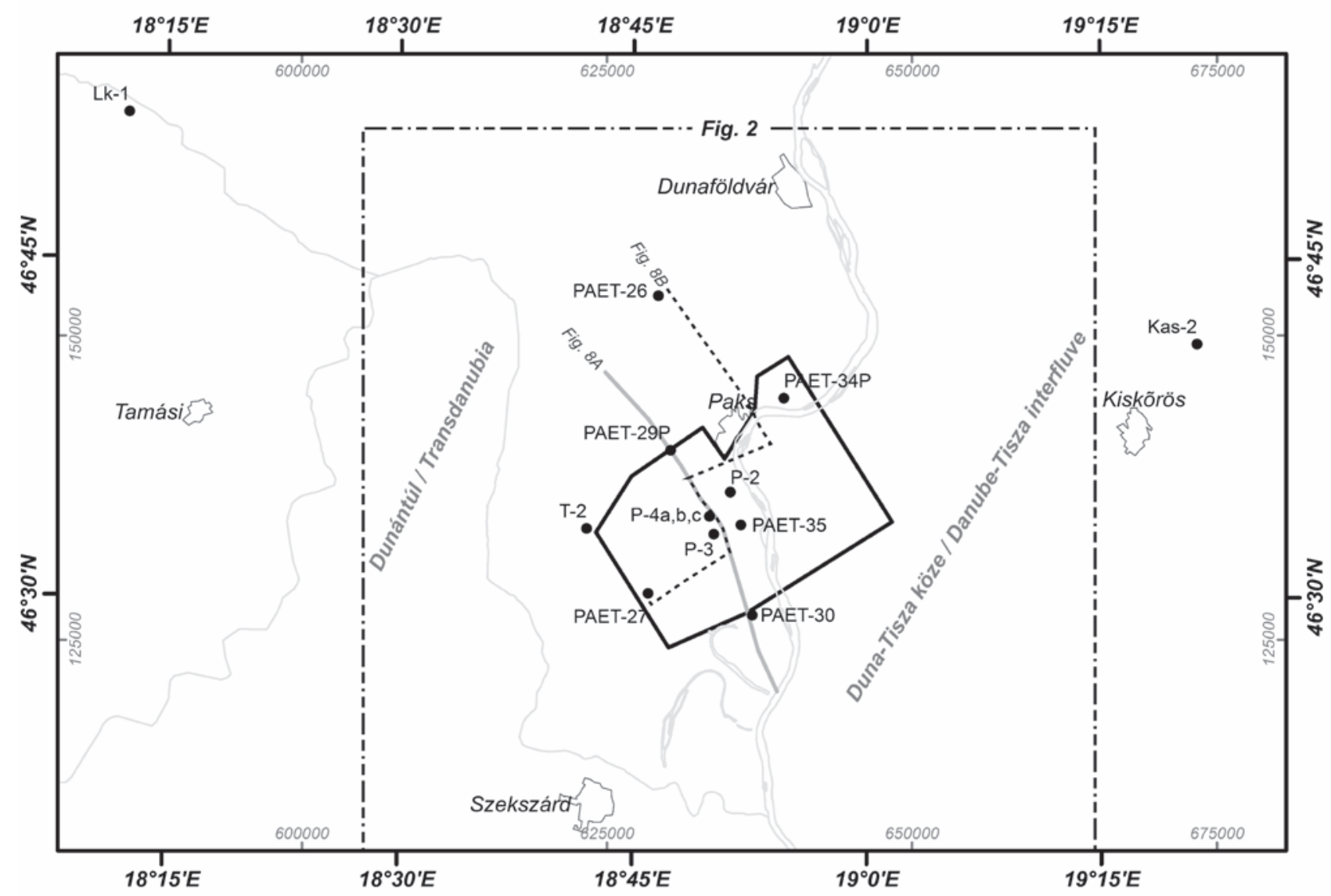

Figure 1. Location map showing the discussed new stratigrapic and old hydrocarbon exploring/stratigraphic wells and the Paks 3D seismic cube (with geographical coordinates and EOV coordinate system)

1. ábra. A szövegben tárgyalt fúrások és a paksi 3D szeizmikus tömb helyszínrajza (földrajzi és EOV koordinátarendszerben) 
now. Micropaleontological samples were taken from the clayey and silty intervals, and they were subject to standard procedures to obtain palynological preparates and to recover the ostracod assemblages. For the biostratigraphic evalua- tion of molluscs and dinoflagellates, the correlation system of MAGYAR \& GEARY (2012) was tentatively used. Ostracod assemblages were assigned into the biozones of SzUROMIKoRECZ (1992). The entire palaeontological material from
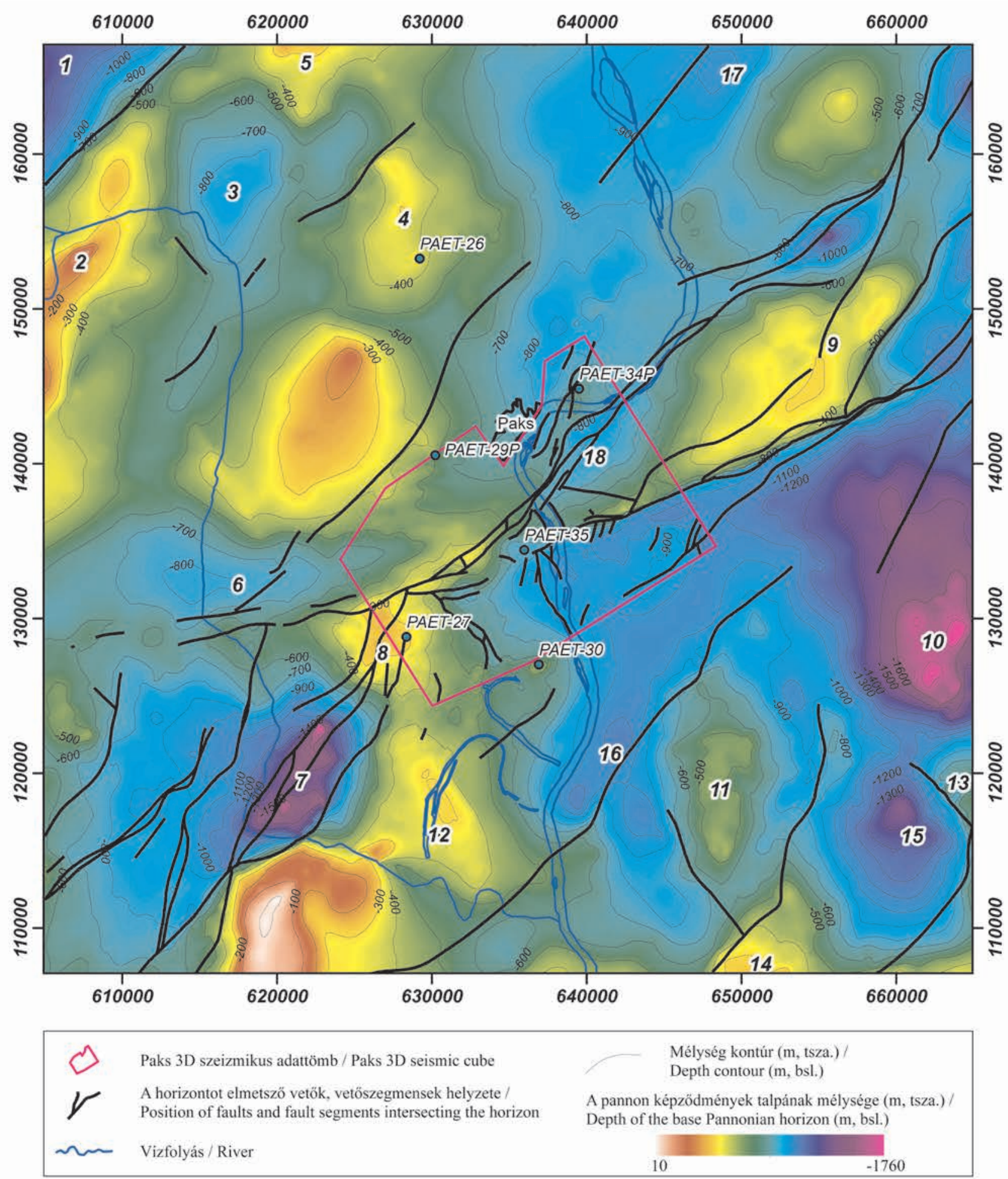

Figure 2. Depth map of the base Pannonian horizon (EOV coordinate system). Numbers indicate the distinguished main morphological elements (cf. Figure 6. of HORVÁTH et al. this volume)

1. Ozora trough 2. Tamási high 3. Simontornya basin 4. Németkér high 5. Sárbogárd high 6. Tengelic-Paks trough 7. Bonyhád basin 8. Tolna high 9. Szentkirály high 10. Kecel trough 11. Miske high 12. Mórágy-Szekszárd high 13. Jánoshalma high 14. Sükösd high 15. Borota basin 16. Fajsz basin 17. Újsolt trough 18. Géderlak trough

2. ábra. A pannóniai emelet talpának mélységtérképe Paks környékén (EOV koordinátarendszerben). A számok a fontosabb aljzatmorfológiai elemeket jelölik (vö. HoRvíTH et al. 6. ábrájával ebben a kötetben) 
Table I. Basic data of the six investigated Pannonian PAET cores

I. táblázat. A hat vizsgált PAET fúrómag pannóniai szakaszainak föbb adatai

\begin{tabular}{|c|c|c|c|c|c|c|}
\hline Core name & $\begin{array}{l}\text { Base Pannonian } \\
\text { (measured depth } \\
\text { in } \mathrm{m} \text { ) }\end{array}$ & Underlying unit & $\begin{array}{l}\text { Top Pannonian } \\
\text { (measured depth } \\
\text { in } \mathrm{m} \text { ) }\end{array}$ & $\begin{array}{c}\text { Thickness or core } \\
\text { length }(\mathrm{m})\end{array}$ & $\begin{array}{c}\text { Authigenic } \\
{ }^{10} \mathrm{Be} /{ }^{9} \mathrm{Be} \text { dating }\end{array}$ & $\begin{array}{l}\text { Magneto- } \\
\text { stratigraphy }\end{array}$ \\
\hline PAET-26 & 500,6 & metamorphite & 13,7 & 486,9 & 9 samples & not reliable \\
\hline PAET-27 & 416,3 & Badenian & 26 & 390,3 & 2 samples & not reliable \\
\hline PAET-29P & 605,8 & Sarmatian & 15,2 & 590,6 & $\begin{array}{l}7 \text { samples in } \\
\text { progress }\end{array}$ & not sampled \\
\hline PAET-30 & 523 & Triassic & 38,8 & 484,2 & $\begin{array}{l}7 \text { samples in } \\
\text { progress }\end{array}$ & reliable \\
\hline PAET-34P & 677 & $\begin{array}{c}\text { Badenian or } \\
\text { Sarmatian }\end{array}$ & 14,7 & 662,3 & $\begin{array}{l}9 \text { samples in } \\
\text { progress }\end{array}$ & reliable \\
\hline PAET-35 & 823 & Sarmatian & $\mathrm{N} / \mathrm{A}$ & 52,4 & not sampled & not reliable \\
\hline
\end{tabular}

the PAET cores was donated by Paks II Ltd. to the Hungarian Natural History Museum, Budapest, where it is being catalogued and reposited.

Reconstruction of the base Pannonian surface and chronostratigraphic correlation between the cores were carried out by seismic methods. Seismic interpretation of the base Pannonian geological horizon within the study area was performed using an integrated, quality-checked geological-geophysical dataset. This dataset included the Paks 3D seismic cube (acquisited in 2014), all available previous and recent 2D seismic data, as well as relevant archive wells of hydrocarbon exploration, water prospecting, stratigraphic studies and the new PAET wells (for a summary of the dataset see Figure 4 of HoRvÁtH et al. this volume). For the geological and methodological background of seismic interpretation, as well as the methods used during map construction the reader is referred to WóRUM et al. (2015). Seismic stratigraphic correlations between wells PAET-26, -27, -29P, -30, and -34P were carried out on 2D seismic lines. (Correlation of PAET35 has not been performed yet, because this well is located off the existing 2D network.) For each well in the 2D correlation, the time/depth function of the nearby Zomba-1 hydrocarbon prospecting well was used.

Eleven samples from two cores (PAET-26, -27) were subject to authigenic ${ }^{10} \mathrm{Be} /{ }^{9} \mathrm{Be}$ dating procedure. The authigenic ${ }^{10} \mathrm{Be} /{ }^{9} \mathrm{Be}$ dating method is based on the measurement of the ratio of ${ }^{10} \mathrm{Be}$ versus ${ }^{9} \mathrm{Be}$ nuclides in the authigenic phase of sediments. The radioactive ${ }^{10} \mathrm{Be}\left(\mathrm{t}_{1 / 2}=1.39 \pm 0.01\right.$ Ma; ChmelefF et al. 2010, KorschineK et al. 2010) is formed as a cosmogenic nuclide in the atmosphere and transferred to the Earth's surface mainly by precipitation (RAISBECK et al. 1981), where it is attached to the surface of fine grained sediments (WITTMANN et al. 2012). The stable ${ }^{9} \mathrm{Be}$ is derived chemically from weathering rock masses. If the initial ratio $\left(\mathrm{R}_{\mathrm{ini}}\right)$, i.e. the ${ }^{10} \mathrm{Be} /{ }^{9} \mathrm{Be}$ ratio at the time of sedimentation can be constrained, the radioactive decay of ${ }^{10} \mathrm{Be}$ enables to calculate the time elapsed since sediment burial (BourLÈs et al. 1989). Accordingly, the $\mathrm{R}_{\mathrm{ini}}$ has a key role in the age determination. It depends on the climate, drainage basin lithologies and sedimentary environment, as these factors determine the abundances of ${ }^{10} \mathrm{Be}$ and ${ }^{9} \mathrm{Be}$ nuclides in the water column at the time of sedimentation.
The samples were processed and their ${ }^{9} \mathrm{Be}$ content was determined using Atomic Absorption Spectrophotometer at CEREGE (Aix en Provence, France). The accelerator mass spectrometry (AMS) measurement of their ${ }^{10} \mathrm{Be} /{ }^{9} \mathrm{Be}$ ratio was performed at the French national AMS facility, ASTER (in CEREGE), calibrated against the NIST SRM 4325 standard material with an assigned ${ }^{10} \mathrm{Be} /{ }^{9} \mathrm{Be}$ ratio of $(2.79 \pm$ $0.03) \times 10^{11}$. The detailed methodology and laboratory procedures applied during the authigenic isotope dating is described in LEBATARD et al. (2008) and ŠUJAN et al. (2016).

Five drill cores (PAET-26, -27, -30, -34P, -35) were sampled for magnetostratigraphic purposes. As the results of magnetostratigraphic investigations were already published by KELDER et al. (2018), the reader is referred to that paper for the description of applied methods.

\section{The study area and location of the cores}

The study area has a transitional position between the typical deep basins of Transdanubia (e.g. Ozora trough, TÖRŐ et al. 2012, SzTANó et al. 2013a) and the Danube-Tisza interfluve (e.g. Kiskunhalas trough, BALÁzs et al. 2016, LEMBERKOVICs et al. 2017). The area was characterised by a moderate subsidence rate during the Pannonian. The depth map of the base Pannonian horizon (Figure 2) displays the most important morphological elements (highs and basins) of the substrata. Comparing this map to the depth map of the pre-Cenozoic basement (see Figure 6. of HoRvÁTH et al. this volume), a rather similar morphological picture can be recognised. Nevertheless, as a consequence of the intense Early and Middle Miocene syn-rift sedimentation and associated volcanic activity, the base Pannonian horizon, representing the post-rift phase of the PBS, displays a morphologically much more smoothed, less fragmented character. Furthermore, some shifts in the position of the center of certain basins/troughs can be also observed. The main depocenters during the Pannonian were the Ozora trough in the north-west, the Kecel trough in the east, as well as the Borota and Fajsz basins in the south-east, and the Bonyhád basin in the south-west (Figure 2). The depth of the base Pannonian horizon exceeds $1000-1500 \mathrm{~m}$ (bsl) in these basins, whereas it has a very shallow position (100-300 m 
bsl) above the neighbouring highs. In addition to these main depocenters, several minor, fault-bounded, elongated ovalshaped subbasins are also observable to the east/east-northeast of Paks (Figure 2). These are interpreted as small pullapart basins formed during Pannonian transtension. For a detailed characterisation of the mapped faults the reader is referred to the work of HoRvátH et al. (this volume).

Among the 6 investigated PAET wells, PAET-26 was drilled above the Németkér high, PAET-27 above the Tolna high, PAET-30 above the north-eastern spur of the MórágySzekszárd high, whereas PAET-34P was positioned in the Géderlak trough, PAET-35 in the westernmost part of the Kecel trough, and PAET-29P is located in an intermediate position on the western flanks of the Géderlak trough (Figure 2).

\section{Description of the cores}

\section{Sedimentary facies and depositional environments}

\section{Profundal marls \\ (Endrôd Formation)}

The beginning of deposition, and the thickness of the profundal marls comprising the Endrôd Formation, depended on the initial basin floor topography. Initial basin floor relief was slightly modified by post-Pannonian deformation (TÖRŐ et al. 2012, SzTANÓ et al. 2013b): highs probably became higher while lows became somewhat deeper, but the present-day morphology of the base Pannonian surface reflects the original one. Therefore, relatively thick Pannonian successions were drilled in the Kecel and Géderlak troughs. These overlay late Middle Miocene (Sarmatian) deposits (breccias and sandstones in PAET29P and -34P and pebbly marls in PAET-35). In these wells, the lacustrine succession may conformably follow the Sarmatian and began with open-water calcareous marls (Tótkomlós Member of Endrőd Formation; Figure 3). These marls are white to light-grey, massive, and contain a lot of molluscs and ostracods. In addition to fully bioturbated beds, a dense network of burrows displayed by variations of the colour also occur. Laminated dark marls with pyrite clusters were also found rarely. The thickness of the calcareous marl is less than $30 \mathrm{~m}$. With the upward decreasing of the carbonate content, it is overlain by silty marl to siltstone, sometimes containing very thin, graded sandstone intercalations. In PAET-29P, situated on the flank of the Géderlak high, the thickness of the marl is only a few metres. Its uppermost surface contains calcite-filled fissures, and is sharply overlain by a pebbly sand.

On local highs, the Pannonian succession unconformably overlies different types of basement units: Palaeozoic schist in PAET-26, Triassic dolomite in PAET-30, and Middle Miocene (Badenian) fossiliferous limestone in PAET-27. Lacustrine sedimentation began with either a less-than-a-metre-thick pebbly sand (PAET-26) interpreted as a transgressive lag, or a 6-m-thick oligomictic conglomerate of abrasional origin (PAET-30). The 5-m-thick, poorly sorted sand above the brecciated surface of the calcareous marl in PAET-29P might also be the product of wave reworking. The basal clastics or the unconformity is overlain by sand-free, mostly bioturbated, organic-rich, slightly micaceous claystones-siltstones. Pyrite clusters, solitary mollusc shells, fish scales, rarely fish skeletons and plant debris occur. These beds represent the Nagykörú Clay Marl Member of the Endrôd Formation, the thickness of which varies between 15-120 m (thinner on the highs and thicker towards the relatively deep areas; Figure 3).

Both the calcareous and clay marls are profundal lacustrine deposits. Their depositional conditions, including the water depth, slightly varied. The calcareous marls were deposited when any sort of clastic input was far enough, so the amount of suspended matter was significantly less than during the deposition of the clay marl. The latter indicates the approach of the clastic feeder systems, yet only mud accumulated in the area. In both settings, the depositional depth could reach a few hundred metres. The lake bottom was well aerated for most of the time, but the occurrence of laminated intervals points to intermittent dysoxic conditions.

\section{Slope shales and sands (Algyő Formation)}

The next deposits in all wells are micaceous siltstones, commonly with frequent, very thin, very fine-grained sandy intercalations. Some sand laminae are only a few grains thick, whereas others may attain a thickness of a few mm or $\mathrm{cm}$. Plane or cross lamination and convolution may occur, but no graded beds or Bouma-sequences were detected. The thickness of the sand beds and the sand/shale ratio repeatedly increases in 20-35 m thick intervals, particularly towards the top of the formation. Scattered mollusc shells are rare, but shell beds occur repeatedly at the base of these coarsening-up units. The dip of the beds is larger than in the underlying unit, it attains $5^{\circ}$. In PAET-29P and -34P, 2-5 m thick folded, chaotic beds with a dip up to $50^{\circ}$ occur; these are interpreted as slump folds (Figure 3).

These beds are representing the slope connecting the basin with the shelf. On the highs, the thickness of the slope deposits is only about $80 \mathrm{~m}$, while towards the troughs it increases to $115-140 \mathrm{~m}$. Taking into consideration the compaction that affected the slope deposits, these thickness values indicate 120-300 m of water depth during deposition. In PAET-35, which is the structurally deepest well, the thickness of the slope deposits can be 200-250 m, corresponding to 300-500 $\mathrm{m}$ water depth. Slopes with less than $100 \mathrm{~m}$ thickness are difficult to recognise on seismic profiles due to resolution issues (cf. UHRIN \& SzTANó, 2012). Turbidite sandstones associated with the Algyő toeof-slope did not deposit on the highs, and turbidites of the Szolnok Formation are also missing here. The lack of both types of turbidite system indicates a bypass zone for the clastic sediments on these slopes. 


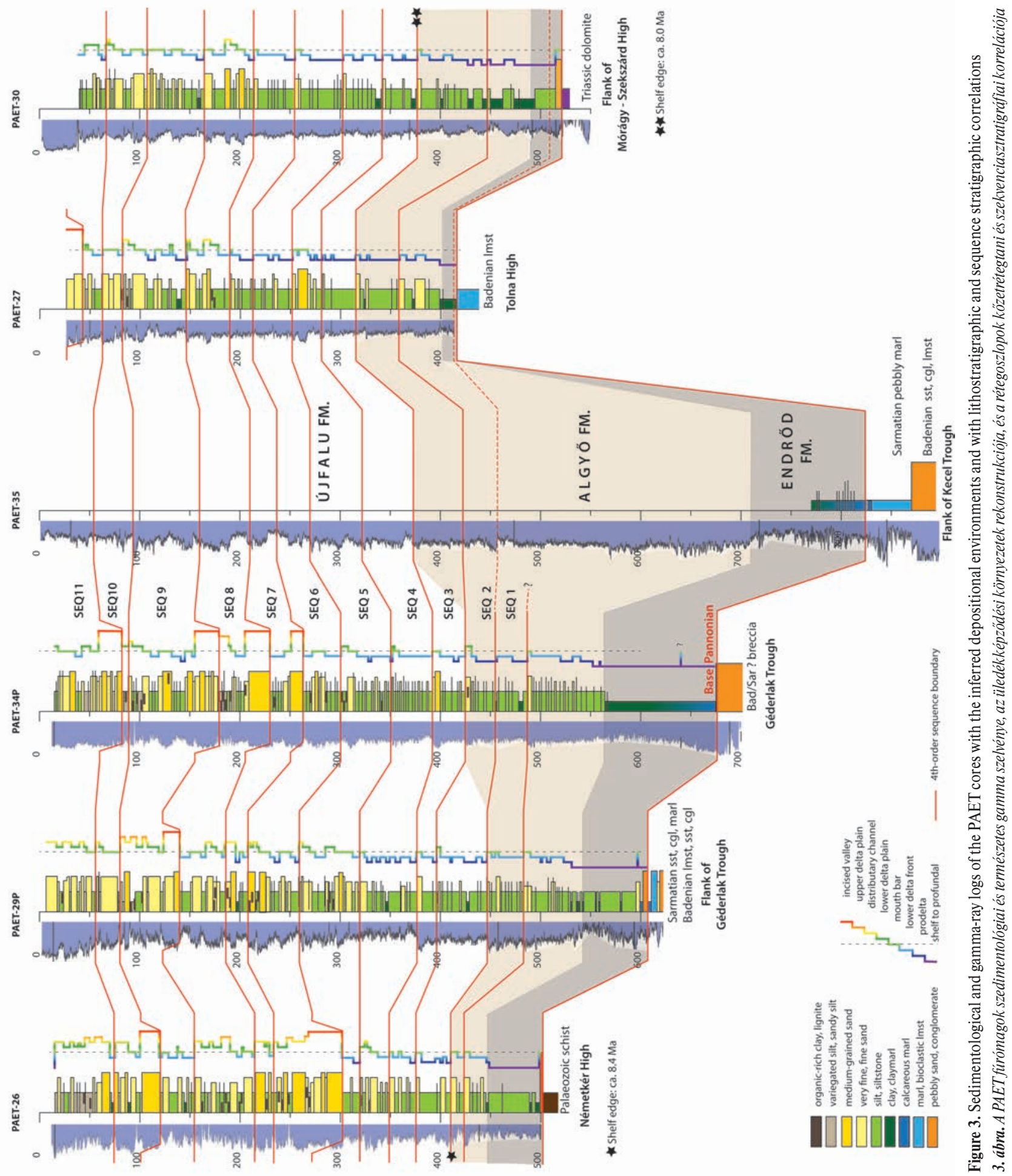


Delta lobe shales, sands, and organic-rich beds (Újfalu Formation)

Above the slope deposits, several stacked deltaic lobes developed, comprising coarsening upwards cycles at different scales. The prodelta is represented by clean laminated mudstones or mud-rich heterolithic facies. Shell-beds are common in the basal part of the mudstones. The increasing ratio of very fine and fine, massive or cross-laminated sandstones, slump folds, and vertical to oblique burrows indicates delta front and distal mouth bar environments. Several meter thick massive, cross-laminated to cross-bedded successions and occurrence of plane-lamination point to the proximal delta front, i.e. flood or wave-dominated mouth bars. The lower delta plain is characterised by heterolithics, organic-rich silts and sands, plant detritus, intense bioturbation, and mottling. Variegated clays and less than dm-thick lignite beds are common on the upper delta plain. Scattered bivalve and gastropod shells occur everywhere in the successions. Few metres thick, fining up series of fine, cross-bedded sand topped by organic-rich heterolithics, are inter-distributary channel fills cutting into the plain. In contrast, 10-33 m thick, cross-bedded, medium to coarse-grained sands represent major conduits of transport, which were occasionally deeply incised into the deltaic successions (Figure 3).

The alternation of the above facies comprises shallowingup cycles, i.e. lacustrine parasequences. The thickness of parasequences varies from 8 to $35 \mathrm{~m}$, but no systematic change was observed. In the lower part of the succession, each cycle is made up of alternations of prodelta and delta front deposits with a well-expressed progradational stacking of the parasequences, often separated by shell-beds. In the upper part, however, deltaic cycles are represented by alternations of mouth bar, lower to upper delta plain and channel-fill deposits, and aggradational to progradational stacking is characteristic. These changes reflect the overall normal regression resulting in gradual infill of Lake Pannon. Based on the stacking pattern and the incised valley fills, at least 10 sequences were correlated in the shallow-water sediments (Figure 3).

After the prograding slope left the area, deltaic deposits of the Újfalu Formation sedimented at least up to a thickness of $400 \mathrm{~m}$. The fluvial feeder system (Zagyva Formation) is not known from the study area, due to uplift and erosion during the Pliocene to Quaternary. The Pannonian strata are directly overlain by Quaternary coarse clastics.

\section{Fossils and biostratigraphy}

All the six cores were investigated for molluscs, ostracods, and palynology. Apart from core PAET-35 where continuous sedimentation across the Sarmatian-Pannonian boundary can be supposed but no age-diagnostic fossils have been recovered so far, the oldest fossil association was identified in PAET-29P. At a depth of $603 \mathrm{~m}$, small cardiids

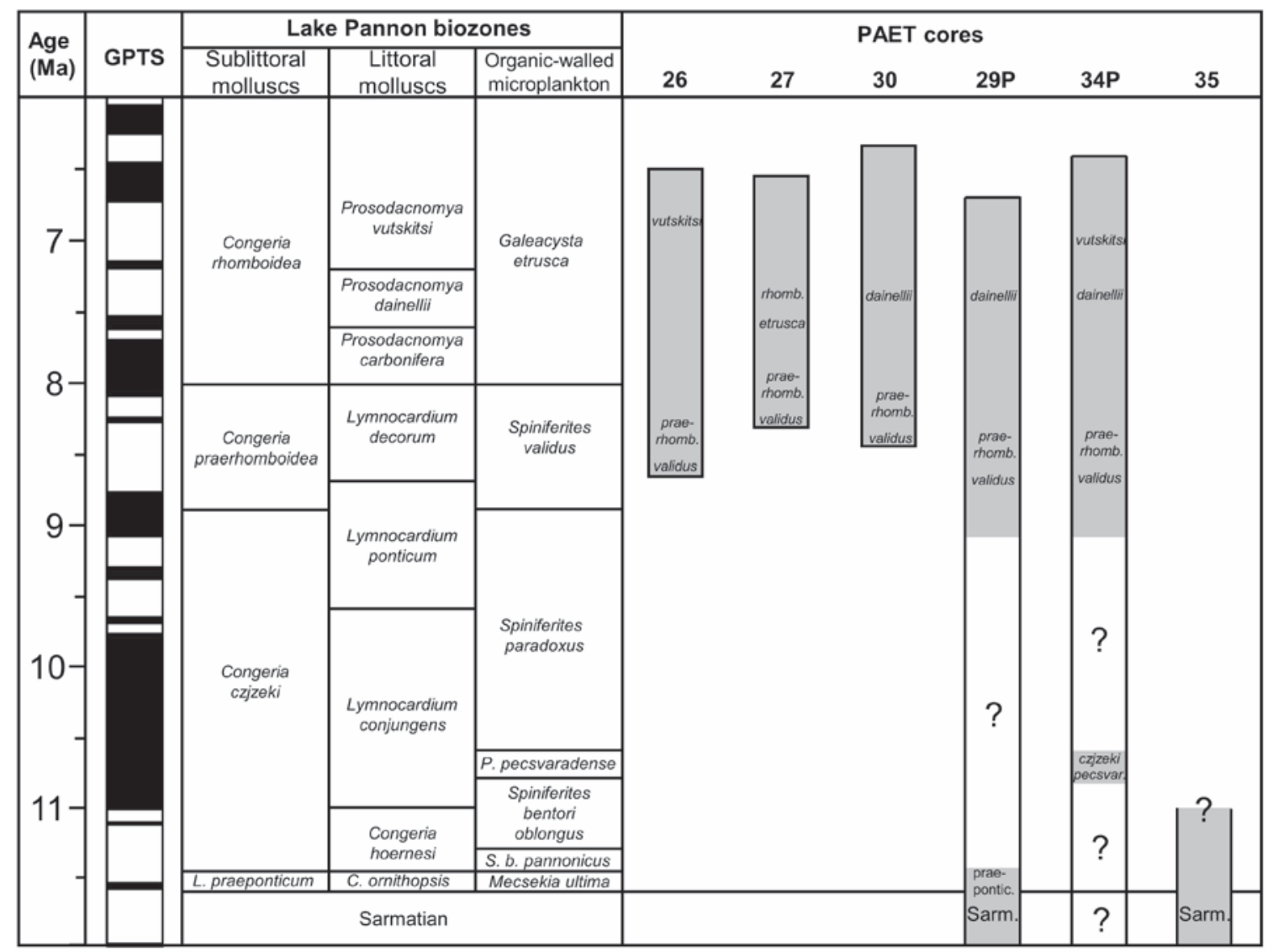

Figure 4. Identified biozones in the PAET cores and their position in the biochronostratigraphic system of MAGYAR \& GEARY (2012) 4. ábra. A PAET fúrómagokban eddig azonositott biozónák és azok idöbeli poziciója MAGYAR \& GEARY (2012) biokronosztratigráfiai rendszerében 
and Radix croatica, an index fossil (snail) of the Lymnocardium praeponticum Zone (11.6-11.4 Ma according to MAGYAR \& GEARY 2012) were recognised (Figure 4).

The second oldest biostratigraphic unit identified so far, the Pontiadinium pecsvaradense Zone (10.8-10.6 Ma), was found in core PAET-34P, at a depth of $664 \mathrm{~m}$ (Figure 4), based on the common occurrence of Spiniferites ramosus, Pontiadinium pecsvaradense and Spiniferites bentorii pannonicus (Figure 5). This is in accord with the presence of the sublittoral mollusc Congeria czjzeki (C. czjzeki Zone, 11.4$8.9 \mathrm{Ma}$ ) at the same depth (Figures 4, 6).

Higher up in the cores of PAET-29P and -34P, as well as in the lower parts of PAET-26, -27, and -30, the sublittoral Congeria praerhomboidea Zone (8.9-8 Ma) was identified by the presence of $C$. cf. praerhomboidea and $C$. zagra- biensis. Among dinoflagellates, Impagidinium globosum and Spiniferites validus indicate the correlative Spiniferites validus Zone (Figures 4, 5). In the upper part of core PAET27, the Congeria rhomboidea Zone and the Galeacysta etrusca Zone (both $<8 \mathrm{Ma}$ ) were found (based on the presence of the sublittoral mollusc $C$. rhomboide $a$ and the dinoflagellate species G. etrusca; Figures 4, 5). The other cores displayed littoral molluscs in their upper parts, such as Prosodacnomya dainellii and $P$. vutskitsi, indicating the $P$. dainellii Zone (7.6-7.1 Ma) in PAET-30, -29P, -34P, and the overlying $P$. vutskitsi Zone $(<7.1 \mathrm{Ma})$ in PAET-26 and 34P (Figures 4, 6).

The biostratigraphic interpretation of the ostracods is in progress. SZUROMI-KORECZ (1992) developed an ostracod zonation for drill cores in southeastern Transdanubia
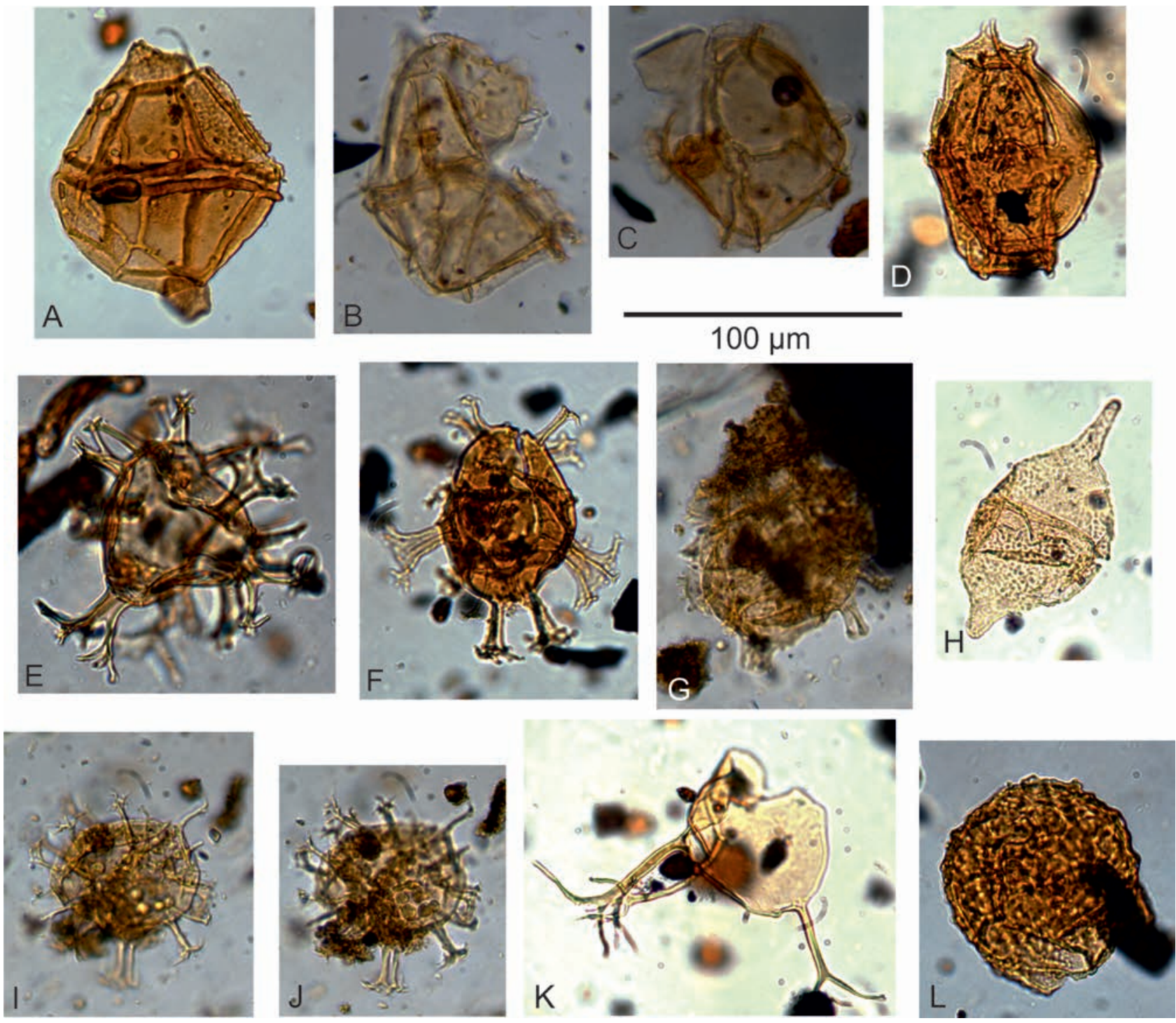

Figure 5. Stratigraphically important dinoflagellates from the PAET cores

A: Pontiadinium pecsvaradensis Sütö-Szentai, PAET-34P, 639.6-639 m; B-C: Galeacysta etrusca Corradini \& Biffi, PAET-27, 237.8-237.7 m; D: Spiniferites balcanicus (Baltes) SütöSzentai, PAET-30, 492.3-492.2 m; E: Spiniferites validus Sütö-Szentai, PAET-34P, 458.06-457.96 m; F: Spiniferites virgulaeformis Sütö-Szentai, PAET-30, 511 -510.95 m; G: Spiniferites bentorii cf. pannonicus Sütö-Szentai, PAET-34P, 663.9-663.7 m; H: Pontiadinium inequicornutum Baltes, PAET-30, 492.3-492.2 m; I-J: Spiniferites ramosus (Ehrenberg) Mantell, PAET-34P, 663.9-663.7 m; K: Achomosphaera andalousiensis Jan du Chęne, PAET-30, 477.47-477.4 m; L: Impagidinium globosum Sütö-Szentai, PAET-29P, 405.5-405.4 m

5. ábra. Rétegtani szempontból fontos dinoflagelláták a PAET fúrómagokból 

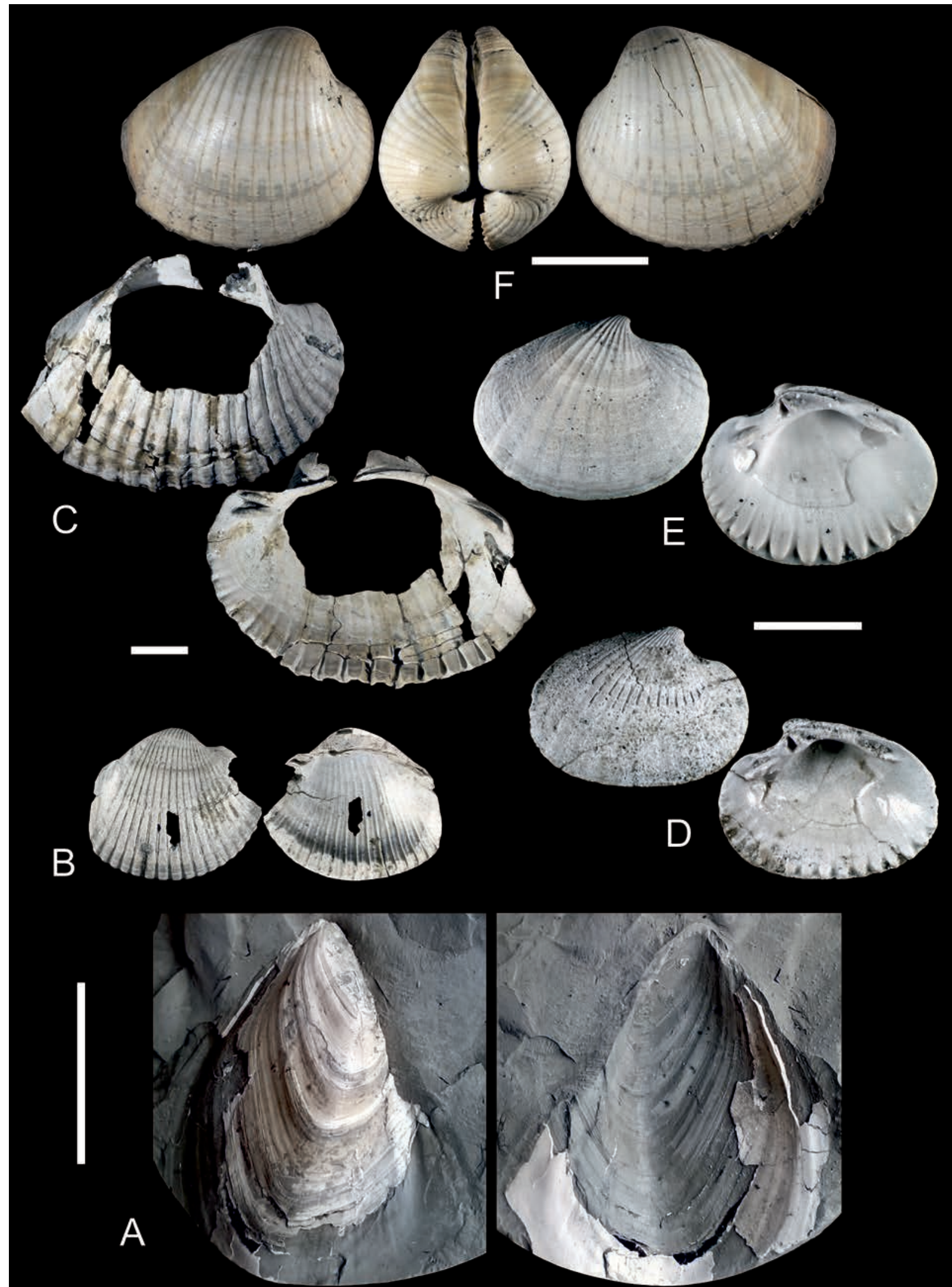

Figure 6. Stratigraphically important molluscs from the PAET cores

A: Congeria czizeki M. Hörnes, PAET-34P, 598.47-598.3 m; B: Lymnocardium penslii (Fuchs), PAET-29P, 438.05-437.73 m; C: L. schmidti (M. Hörnes), PAET-29P, 208.1207.7 m; D: L. diprosopum (Brusina), juvenile specimen, PAET-34P, 392.78-392.63 m; E: L. arpadense (M. Hörnes), juvenile specimen, PAET-29P, 123.12-123 m; F Prosodacnomva vutskitsi (Brusina), PAET-29P, 160.81-160.74 m. Scales: A: 20 mm, B-C, F: 10 mm, E-D: 5 mm

6. ábra. Rétegtani szempontból fontos puhatestüek a PAET fúrómagokból 

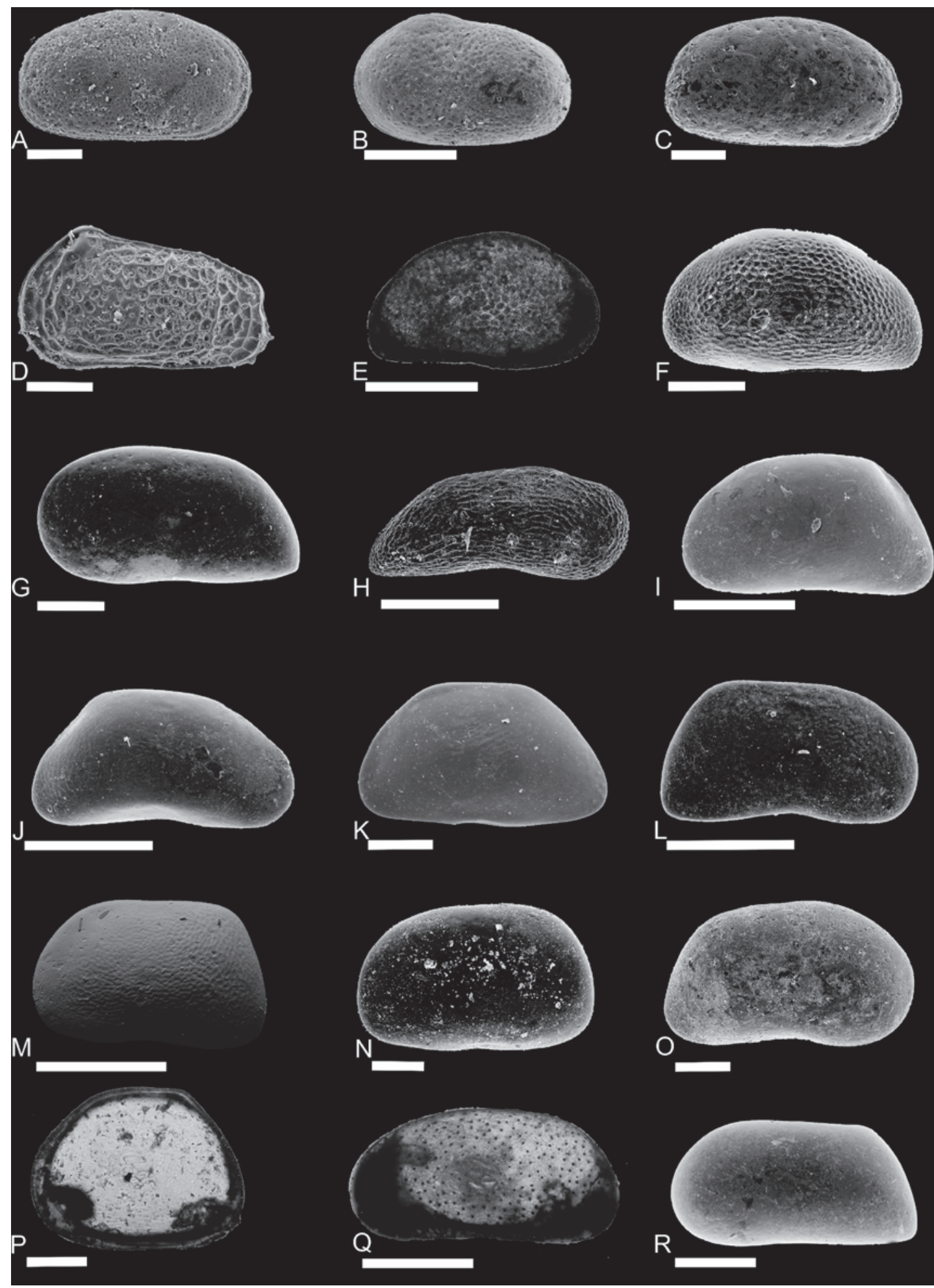

Figure 7. Stratigraphically important ostracods from the PAET cores (in lateral views)

A: Cyprideis (Cyprideis) agrigentina Decima, right valve (RV), PAET-26, 197.6-197.5 m; B: Cyprideis sublittoralis Pokorny, left valve (LV), PAET-26, 486.8486.7 m; C: Cyprideis seminulum (Reuss), RV, PAET-26, 408.9-408.8 m; D: Hemicytheria cf. josephinae Zalányi, LV, PAET-26, 437.9-437.8 m; E: Bakunella dorsoarcuata (Zalányi), RV, PAET-27, 277.4-277.3 m; F: Bakunella cf. guriana (Livental), LV, PAET-30, 142.05-141.95 m; G: Candona (Caspiolla) praebalcanica Krstič, LV, PAET-26, 71.5-71.4 m; H: Candona (Serbiella) sagittosa Krstič, RV, PAET-27, 385.95-385.85 m; I: Candona (Hastacandona) longitesta (Krstič), LV, PAET-30, 142.05-141.95 m; J: Candona (Hastacandona) longitesta (Krstič). Right valve (RV). PAET-30 141.95-142.05 m. K: Candona (Lineocypris) trapezoidea (Zalányi), LV, PAET-27, 216.4-216.3 m; L: Candona (Reticulocandona) orientalis (Krstič), RV, PAET-27, 216.4-216.3 m; M: Candona (Reticulocandona) reticulata (Méhes), LV, PAET-27, 186.5-186.4 m; N: Candona (Thaminocypris) alta (Zalányi), LV, PAET-27, 196.3-196.2 m; O: Candona (Sinegubiella) sublabiata (Krstič), RV, PAET-26, 437.9-437.8 m; P: Cypria tocoriescui Hanganu, LV, PAET-27, 183.85-183.8 m; Q: Amplocypris recta (Reuss), LV, PAET-26, 365.4-365.3 m; R:Amplocyris nonreticulata Krstič, LV, PAET-30, 79.3-79.2 m. Scales: D: 250 um; B, I-L, Q, R: 500 um; others: $200 \mu \mathrm{m}$

7. ábra. Rétegtani szempontból fontos kagylósrákok a PAET fúrómagokból (oldalnézetben) 
(including $\mathrm{P}-3$ and $\mathrm{P}-4 \mathrm{a}$ ), which was partly based on, and modified from, the zonation of KRSTIĆ (1985). The oldest ostracod biostratigraphic unit identified so far from the PAET cores is the Hemicytheria croatica Zone (sensu SzUROMIKoRECZ 1992) in PAET-29P, $594 \mathrm{~m}$. In this sample, the dominance of Cyprideis ex. gr. macrostigma and lack of "Pontian" species (sensu KRSTIĆ 1985) indicate the uppermost part of the „Pannonian s. str.”, which is correlated with the upper part of the Congeria czjzeki Zone (11.4-8.9 Ma) by SzUROMI-KoreCZ (1992). The younger Sinegubiella sublabiata - Amplocypris nonreticulata and Bakunella dorsoarcuata - Thaminocypris pontica Zones (SZUROMIKoRECZ 1992) were identified in all PAET cores, except for PAET-35 (Figure 7).

Biostratigraphic assignment was often difficult or impossible in the uppermost part of the cores where strong freshwater influence affected the depositional environments and brackish index fossils are scarce or entirely lacking.

\section{Seismic correlation of the cores}

Based upon the principle that seismic reflectors correspond to palaeosurfaces, chronostratigraphic correlation between the PAET wells was carried out on a network of 2D seismic lines (Figures 1, 8; Table II). The five correlation horizons (H1 to H5) were arbitrarily choosen high amplitude events. In the upper part of the Pannonian sediments, consisting of shallow lacustrine and deltaic deposits, the reflectors are parallel and horizontally continuous. In the lower part of the Pannonian, however, clinoforms of small height (below $100 \mathrm{~ms}$; Figure 8) were detected. These clinoforms clearly reflect progradation of a transitional slope (sensu SzTANó et al. 2015).

Although the study area is segmented by the Kapos Line fault system (HoRvátH et al. this volume), the apparent offset of the correlation horizons at the different fault segments could be determined, thus tracing of individual seismic reflectors across the faults was reliably performed.

\section{Dating of the cores}

\section{Authigenic ${ }^{10} \mathrm{Be}^{\rho} \mathrm{Be}$ dating}

Results from the authigenic ${ }^{10} \mathrm{Be} /{ }^{9} \mathrm{Be}$ dating are available for PAET-26 and PAET-27 cores (Table III), and measurements are in progress with samples processed at the recently launched sample preparation laboratory in Bratislava (ŠUJAN et al. 2018) for PAET-29P, -30, and-34P (Table I).

For the calculation of the authigenic ${ }^{10} \mathrm{Be} /{ }^{9} \mathrm{Be}$ ages, initial ratios derived from data published by ŠUJAN et al. (2016) were applied. They collected and measured Late Pleistocene and Holocene samples from shallow lakes with limited drainage areas in the Western Pannonian Basin $(n=5)$ and from the recent floodplain of the Danube Basin dominated by the Danube and its Western Carpathian tributaries (Vah,
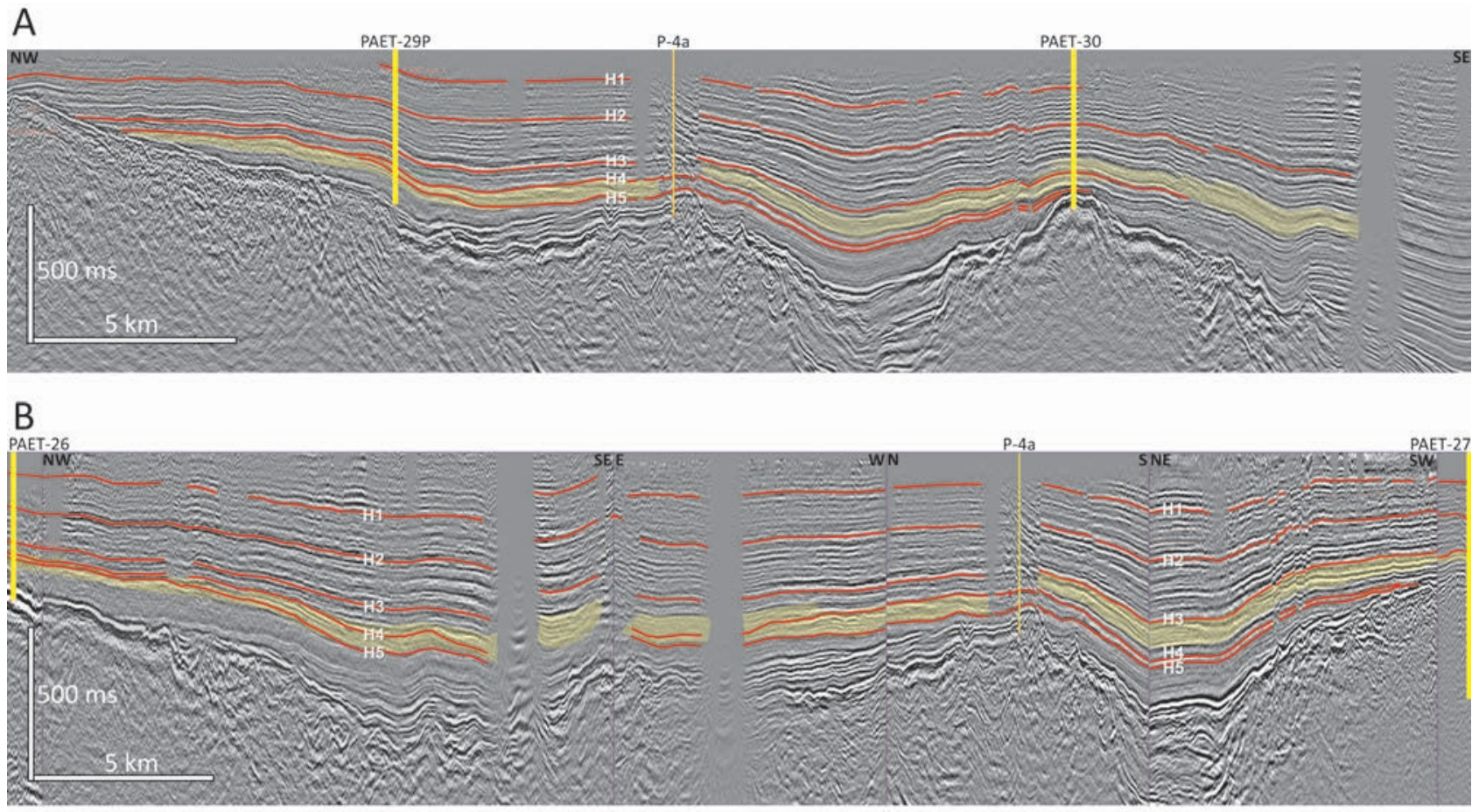

Figure 8. Seismic stratigraphic correlation between A) PAET-29P and PAET-30 and B) PAET-26 and PAET-27 cores on 2D seismic profiles. Clinoform sets are highlighted with yellow. Location of profiles in Figure 1

8. ábra. Szeizmikus rétegtani korreláció 2D szelvényeken a PAET-29P és PAET-30 fúrások között (A), illetve a PAET-26 és PAET-27 fúrások között (B). A klinoform sorozatokat sárga szín jelöli. A szelvények nyomvonala az 1. ábrán látható 
Table II. Seismic correlation between the PAET wells (using 2D seismic data)

II. táblázat. Szeizmikus korreláció a PAET fúrások között (2D szeizmika felhasználásával)

\begin{tabular}{|l|c|c|c|c|c|}
\hline Horizon & $\begin{array}{c}\text { Measured depth in } \\
\text { PAET-26 }(\mathrm{m})\end{array}$ & $\begin{array}{c}\text { Measured depth in } \\
\text { PAET-27 }(\mathrm{m})\end{array}$ & $\begin{array}{c}\text { Measured depth in } \\
\text { PAET-29P }(\mathrm{m})\end{array}$ & $\begin{array}{c}\text { Measured depth in } \\
\text { PAET-30 }(\mathrm{m})\end{array}$ & $\begin{array}{c}\text { Measured depth in } \\
\text { PAET-34P }(\mathrm{m})\end{array}$ \\
\hline H1 & 160 & 140 & 140 & 155 & 155 \\
\hline H2 & 270 & 235 & 260 & 280 & 265 \\
\hline H3 & 365 & 355 & 400 & 450 & 425 \\
\hline H4 & 420 & onlaps & 470 & 515 & not correlated \\
\hline H5 & 415 & onlaps & 495 & onlaps & not correlated \\
\hline
\end{tabular}

Nitra, Hron) ( $\mathrm{n}=11)$, and calculated a weighted mean value for both (mean $\mathrm{R}_{\mathrm{ini}}$ lacustrine: $(6.97 \pm 0.14) \times 10^{-9}$; mean $\mathrm{R}_{\mathrm{ini}}$ alluvial: $\left.(4.14 \pm 0.17) \times 10^{-9}\right)$. Accordingly, in this study the authigenic ${ }^{10} \mathrm{Be} /{ }^{1} \mathrm{Be}$ ages were calculated using both fluvial and lacustrine initial ratios (Table III).

Independently of the selection of the $\mathrm{R}_{\mathrm{in}}$, the results show that the Pannonian sequence in both PAET-26 and -27 represents a time span of approximately $2 \mathrm{Myr}$. The calculated ages - considering their uncertainties - follow the chronological order with increasing trend of authigenic ${ }^{10} \mathrm{Be} /{ }^{9} \mathrm{Be}$ ages with depth. Calculated age of the PAET-26, $433 \mathrm{~m}$ sample is out of this trend; therefore, it is considered as an outlier and it is skipped from further discussion.

\section{Magnetostratigraphy}

Five Paks cores were sampled for magnetostratigraphic investigations of the Pannonian successions: PAET-26 (328 samples), PAET-27 (280), PAET-30 (344), PAET-34P (486), and PAET-35 (122). Demagnetisation behaviour of 7 test samples from PAET-35 was not promising for constructing a magnetostratigraphy, therefore no further samples of the core were measured. Because sample quality and resolution was not satisfactory in PAET-26 and -27 either, only PAET-30 and -34P were used for magnetostratigraphic correlation (KELDER et al. 2018).

Rock magnetic and SEM investigations showed that all magnetic components of the samples reside in diagenetically forming greigite. Thermal demagnetisation behaviours made it possible to distinguish the magnetic components associated with early diagenetic greigite from the components that are the results of a late diagenetic overprint (KeLDER et al. 2018).

As a result, the PAET -30 core displays 4 normal and 5 reversed intervals. Taken into consideration that the biochronostratigraphic model restricts the age of the core to

Table III. Authigenic ${ }^{10} \mathrm{Be}$ and ${ }^{9} \mathrm{Be}$ abundances, ${ }^{10} \mathrm{Be} /{ }^{9} \mathrm{Be}$ ratios, and ages calculated with lacustrine and with fluvial initial ratio (initial ratios are from ŠUJAN et al. 2016)

III. táblázat. Az autigén ${ }^{10}$ Be és ${ }^{9}$ Be mennyisége, ${ }^{10}$ Be ${ }^{9}$ Be arányok és korok tavi és folyóvizi kiindulási izotóparánnyal számolva (kiindulási izotóparányok ŠUJAN et al. 2016 alapján)

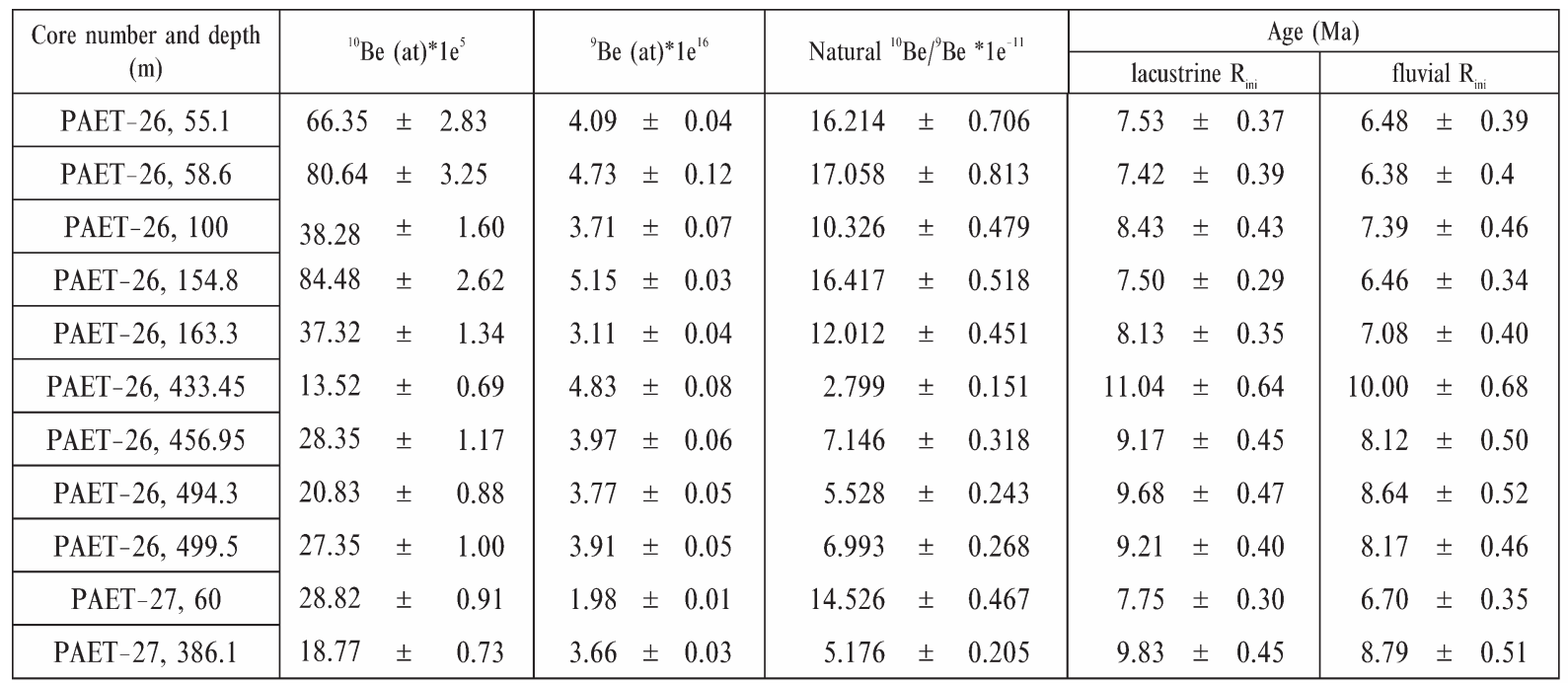

Authigenic ${ }^{10} \mathrm{Be}$ and ${ }^{9} \mathrm{Be}$ abundances, ${ }^{10} \mathrm{Be} /{ }^{9} \mathrm{Be}$ ratios, and ages calculated with lacustrine and with fluvial initial ratio (initial ratios are from ŠUJAN et al. 2016: Lacustrine $\mathrm{R}_{\mathrm{in}}:\left[6.97 \pm 0.14\left[\times 10^{-9}\right.\right.$; fluvial $\left.\mathrm{R}_{\mathrm{in}}:[4.14 \pm 0.17] \times 10^{-9}\right)$. The measured ${ }^{10} \mathrm{Be} /{ }^{9} \mathrm{Be}$ ratios were corrected for the long term average process blank ${ }^{10} \mathrm{Be} /{ }^{9} \mathrm{Be}$ ratio of $2.32 \times 10^{-15}(0.7-3.4 \%$ of the measured values). Analytical uncertainties (reported as $1 \sigma)$ include uncertainties associated with AMS counting statistics, ${ }^{9} \mathrm{Be}$ measurements and AMS internal error (0.5\%; (ARNOLD et al. 2010). The uncertainties of the calculated ages include the uncertainty of the initial ratio, of the half-life and the analytical uncertainty of the natural ${ }^{10} \mathrm{Be} /{ }^{9} \mathrm{Be}$ ratio.

Az autigén ${ }^{10} \mathrm{Be}$ és ${ }^{9} \mathrm{Be}$ mennyisége, ${ }^{10} \mathrm{Be}{ }^{9} \mathrm{Be}$ arányok és korok tavi és folyóvízi kiindulási izotóparánnyal számolva (kiindulási izotóparányok ŠUJAN et al. 2016 alapján: tavi $R_{\text {ini: }}$ : $[6.97 \pm 0.14] \times 10^{-9}$; folyóvízi $\left.R_{\text {ini: }}:[4.14 \pm 0.17] \times 10^{-9}\right)$. A mért ${ }^{10}$ Be ${ }^{9}$ Be arányok a kémiai vakminta $2.23 \times 10^{-15}$, hosszútávú átlagos ${ }^{10} \mathrm{Be}{ }^{9} \mathrm{Be}$ arányával lettek korrigálva (a mért értékek 0.7-3.4\%-a). Az analitikai bizonytalanság (1 szigma) magába foglalja a gyorsító tömegspektrométeres mérés beütésszám-statisztikájának bizonytalanságát és belsó hibáját (0.5\%; ARNOLD et al. 2010). A számított korok bizonytalansága magába foglalja a kiindulási izotóparány, a felezési idó és a ${ }^{10} \mathrm{Be}{ }^{\ominus} \mathrm{B}$ e arány analitikai bizonytalanságát. 
Table IV. Magnetostratigraphic correlation of PAET-30 and -34P polarities to the Global Polarity Timescale of HILGEN et al. (2012)

IV. táblázat. A PAET-30 és-34P fúrások magjain mért mágneses polaritászónák korrelációja HILGEN et al. (2012) globális polaritás időskálájához

\begin{tabular}{|l|l|l|l|}
\hline \multicolumn{2}{|c|}{ GPTS } & PAET-30 & PAET-34P \\
\hline Polarity zone & Age (Ma) & \multicolumn{2}{c|}{ Depth $(\mathrm{m})$} \\
\hline C3Bn top & 7.14 & 158 & $? 186$ \\
\hline C3Bn bottom & 7.212 & 188 & \\
\hline C3Br. $1 n$ top & 7.251 & 200 & \\
\hline C3Br.1n bottom & 7.285 & 217 & $? 206$ \\
\hline C3Br.2n top & 7.454 & 251 & \\
\hline C3Br.2n bottom & 7.49 & & 271 \\
\hline C4n. $1 n$ top & 7.53 & & 280 \\
\hline C4n. $1 n$ bottom & 7.642 & & 309 \\
\hline C4n.2n top & 7.695 & 322 & 330 \\
\hline C4n.2n bottom & 8.108 & 437 & 415 \\
\hline C4r. $1 n$ top & 8.254 & 472 & 434 \\
\hline C4r. $1 n$ bottom & 8.3 & 475 & 438 \\
\hline C4An top & 8.771 & & 617 \\
\hline C4An bottom & 9.105 & & $? 659$ \\
\hline
\end{tabular}

the 9-6 Ma interval, and that the authigenic ${ }^{10} \mathrm{Be} /{ }^{9} \mathrm{Be}$ age data for PAET-26 and -27 , when seismically correlated to PAET-30, suggests a 1.5-2.0 Ma total interval for the core, the correlation to the GPTS (HILGEN et al. 2012) as displayed in Table IV was established. Using the $29 \mathrm{~cm} / \mathrm{ky}$ average sedimentation rate for the core, the extrapolated age of the top of the Pannonian sequence is 6.73, whereas the age of its bottom is $8.47 \mathrm{Ma}$ old, thus the whole Pannonian core of PAET-30 represents $1.74 \mathrm{Ma}$.

The PAET-34P core yielded 5 normal and 5 reversed polarity zones between the depths of 230 and $660 \mathrm{~m}$. Above $230 \mathrm{~m}$, the polarity pattern is difficult to interpret, due to common outliers and thick sandy intervals without reliable data. Below $659 \mathrm{~m}$, the demagnetisation behaviour of the samples discouraged further analysis.

Biostratigraphic data and seismic correlation suggest that the PAET-34P core covers the same stratigraphic interval as PAET-30, but because it is some $150 \mathrm{~m}$ deeper, older units should be represented as well. Therefore, the lowermost normal polarity zone of PAET-34P (617 to ?659 m) was correlated with C4An (Table IV). With the $27 \mathrm{~cm} / \mathrm{kyr}$ average sedimentation rate calculated from the magnetostratigraphic interpretation, the top of the Pannonian sequence is extrapolated to be $6.73 \mathrm{Ma}$ old in PAET-34P. The average sedimentation rate, however, cannot be used to extrapolate the age of the bottom of the sequence, because below $659 \mathrm{~m}$, strongly condensed calcareous marl was deposited (Figure 4)

\section{Discussion and conclusions}

\section{Problem of the condensed intervals}

Continuous sedimentation across the Sarmatian-Pannonian boundary and thus a continuous oldest Pannonian record is rightly supposed for core PAET-35, although more effort is required to identify any biozone in that core. In cores PAET-29P and -34P, however, the presence of old Pannonian biozones and thus continuous sedimentation since the Sarmatian is equivocal and needs further investigation. If condensed intervals are present in the lowermost parts of these cores, then 2.5 Ma of sedimentation are represented by $9 \mathrm{~m}$ calcareous marl in PAET-29P and by $16.5 \mathrm{~m}$ calcareous marl in PAET-34P. The most complete and apparently continuous superposition of old Pannonian dinoflagellate zones was formerly observed in core $\mathrm{P}-3$ (for location see Figure 1), where the Spiniferites paradoxus and Pontiadinium pecsvaradense Zones were identified in a 50 $\mathrm{m}$ thick condensed interval below the widely distributed Spiniferites validus Zone (SüTő-SzENTAI 2000), and this interpretation was also supported by ostracod biostratigraphy (SzUROMI-KorECZ 1992).

Dating of the supposedly old, condensed parts of the cores with either magnetostratigraphy or authigenic ${ }^{10} \mathrm{Be} /{ }^{9} \mathrm{Be}$ method is challenging. Earlier attempts to regain the natural remanent magnetisation in the basal calcareous marls of the Pannonian sequences usually failed (see core PAET-35 or -34P, 676 to $660 \mathrm{~m}$ from this study, the samples from Našice quarry, Croatia, in VASILIEV et al. 2007, or the samples from Beočin, Serbia, in GANIĆ et al. 2010). Unusually low rates of sedimentation may significantly enhance the ${ }^{10} \mathrm{Be} /{ }^{9} \mathrm{Be}$ ratio, thus age calculations based on samples with "normal" sedimentation rates will be highly misleading. Therefore, only detailed biostratigraphic (micropalaeontological and palynological) investigations can confirm or discard the presence of old (11.6 to 9.1 Ma) Pannonian sediments in cores PAET-29P and -34P.

\section{Magnetostratigraphic and authigenic ${ }^{10} \mathrm{Be} / \mathrm{Be}$ dating of the cores - a correlation}

Although the two, independent dating methods were applied to different cores, seismic stratigraphy establishes a chronostratigraphic correlation between the four wells concerned, and thus facilitates the comparison and correlation of the obtained age data. The two datasets give a reasonable correlation if the fluvial $\mathrm{R}_{\mathrm{ini}}$ is used for the calculation of the authigenic ${ }^{10} \mathrm{Be} /{ }^{9} \mathrm{Be}$ ages, whereas the application of the lacustrine $\mathrm{R}_{\text {ini }}$ gives ages which, being systematically older by $\sim 1$ Myr (Table III), cannot be straightforwardly correlated with the measured polarity pattern. This observation suggests that the small and shallow lakes with local and small (or very small) catchments, which served as sampling sites for the calculation of the lacustrine $\mathrm{R}_{\text {ini }}$ of ŠUJAN et al. (2016), are hardly representative for the sedimentary environments of the former delta system filling up Lake Pannon. At least in the Paks area, the fluvial $R_{\text {ini }}$ provided a better base for age calculations, suggesting that the position, size and lithology of the drainage area of the alluvial sampling locations may well represent that of the prograding delta system of Lake Pannon. The better fit of the ages calculated using the fluvial $\mathrm{R}_{\mathrm{ini}}$ to the magnetostratigraphic model suggests that 


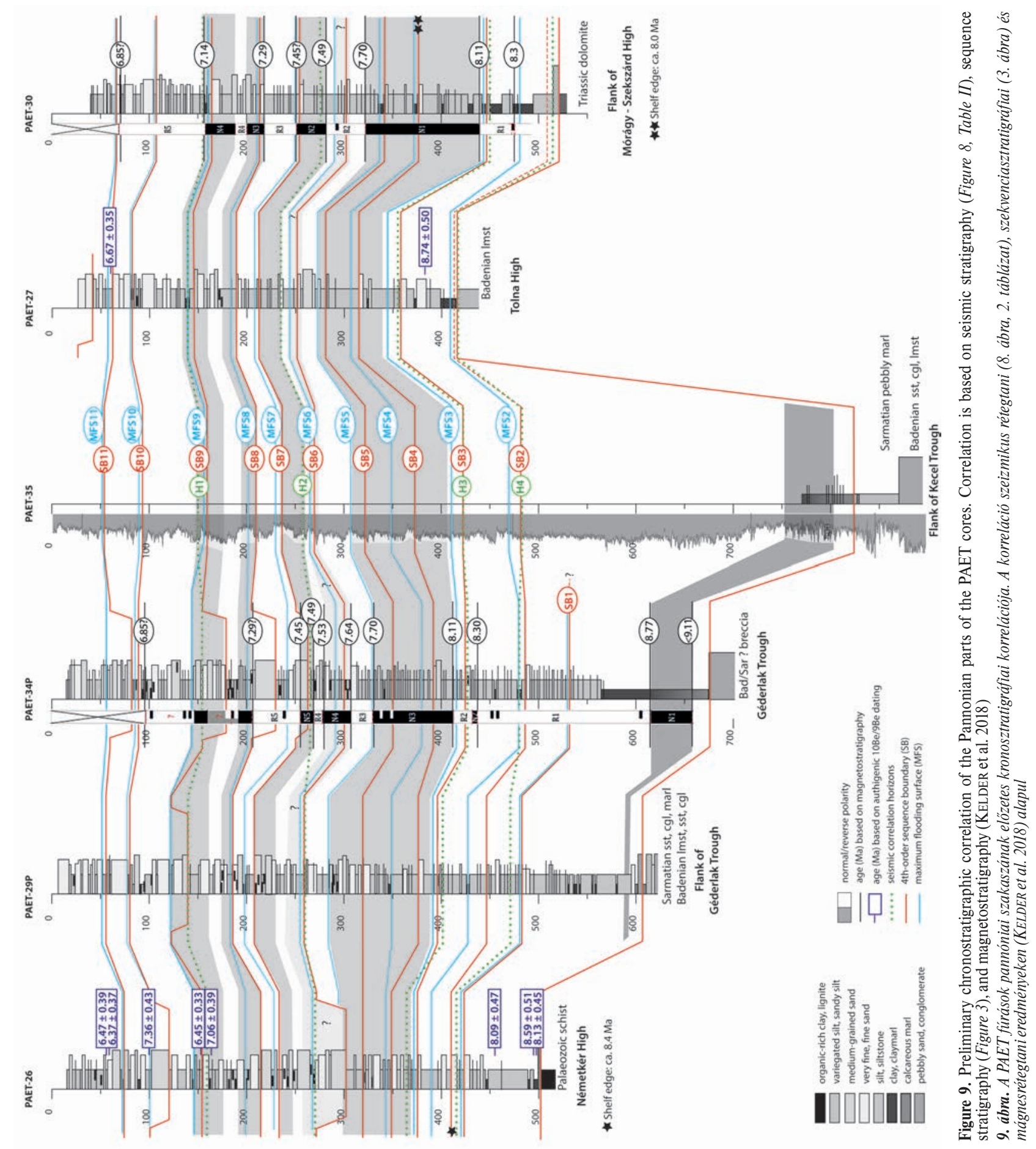


catchment properties have dominant signal over the actual environment of the sample site when defining the initial ratio for the authigenic ${ }^{10} \mathrm{Be} /{ }^{9} \mathrm{Be}$ chronologies.

\section{Towards an integrated chronostratigraphy for thelate Neogene of the PBS}

The novelty of this study is that the chronostratigraphicgeochronological skeleton of the investigated sedimentary sequence was built by seismic stratigraphic, magnetostratigraphic, and authigenic ${ }^{10} \mathrm{Be} /{ }^{1} \mathrm{Be}$ dating methods, independently from the lithological and paleontological content of the cores. Similar attempts in the 1980s-1990s (HoRvátH \& PogácsÁs 1988, PogáCSÁs et al. 1994, VAKARCS et al. 1994) were ahead of their time and attracted attention internationally, but the key drillings were located far from each other making the seismic correlation less reliable, radiometric dating (by $\mathrm{K} / \mathrm{Ar}$ method) was very sparse and had a large uncertainty, and the magnetostratigraphic interpretation of the polarity patterns was not straightforward because the diagenetic greigite obscured the natural remanent magnetisation. Eventually, biostratigraphic data had to be considered for the correlation of the polarity zones with the global polarity timescale (MAGYAR et al. 1999, 2007). In the PAET cores, however, the carefully logged lithological and sedimentological features and the abundant and often excellently preserved fossils can be interpreted in an independent geochronological context. This offers an exceptional opportunity to study the spatial and temporal distribution and evolution of depositional environments, sedimentary sequences, biological species and communities, and biozones.

The preliminary chronostratigraphic correlation of the Pannonian parts of the six PAET wells is shown in Figure 9. The correlation is based on seismic-, sequence-, and magnetostratigraphy. The selected high-amplitude, good-continuity seismic reflectors (H1 to H5) correlate either with maximum flooding surfaces or flooding surfaces, which correspond to the non-incising portions of sequence boundaries.

This correlation confirms that the boundary between the Algyő and Újfalu Formations, i.e. the shelf-break, is ca $4 \mathrm{Ma}$ old in the northernmost PAET-26 core, and ca 8 Ma old in the southernmost PAET-30 core, which is located more than $25 \mathrm{~km}$ SE of PAET-26. Between 8.4 and $6.8 \mathrm{Ma}, 9$ depositional sequences developed. Therefore, the duration of these sequences is not more than $200 \mathrm{kyr}$ each, thus they can be regarded as $4^{\text {th }}$-order sequences. This is in harmony with other observations on climate-driven cyclicity (SACCHI \& Müller 2004, SzTANó et al. 2013b, Gong et al. 2018). The correlation of these fourth-order sequences between the cores could not have been carried out without the support of seismic stratigraphy and magnetostratigraphy. The distance between the wells is $8-12 \mathrm{~km}$. No major sand body, including incised valley-fills, "marker" shales or lignite seams can be correlated either in dip or strike direction to such distances. Due to this lithological variability, most likely related to the local variation in depositional rate, neither the small nor the large-scale stacking patterns are reflected clearly by the well logs. This high-resolution example demonstrates the risk and challenge of purely log-based correlations of deltaic deposits even within several $\mathrm{km}$ distances.

In general, sedimentation rates are supposed to accelerate with progradation. In the PAET cores, however, this is not evident as slope progradation is fairly rapid, thus pace of deposition in form of slope siltstones and sandstones is not significantly less than that on the deltas, particularly between 8.2-7.5 Ma, when no major sand body appears on the transiting deltas. This might be related to the position of major distributaries, which seemingly avoided this area before 7.5 Ma. Later, however, distributaries were present in the northern part of the study area, as indicated by several incised valley fills in cores PAET-26 and -34P.

Preliminary palaeontological data from the PAET wells show a close fit with the former biochronostratigraphic system (MAGYAR \& GEARY 2012). Therefore, we expect that data from the Paks cores will only slightly modify the ages of the established biozone boundaries. These data also seem to confirm earlier hypotheses on some anagenetically evolving lineages in molluscs, such as the Prosodacnomya carbonifera $-P$. dainellii $-P$. vutskitsi (MÜLLER \& MAGYAR 1992), the Lymnocardium penslii - L. schmidti, and the $L$. diprosopum - L. arpadense lineages (GEARY et al. 2010) and their proposed geological time frame (Figure 6).

\section{Future perspectives}

The authigenic ${ }^{10} \mathrm{Be} /{ }^{9} \mathrm{Be}$ dating project is still ongoing, and results from the cores PAET-29P, -30 , and $-34 \mathrm{P}$ will show the power and the limits of this method. Seismic correlation will be continued towards the fully cored $\mathrm{P}-2$, $3,-4 a, b, c, L k-1, T-2$, and Kas-2 wells, thus more sedimentological and paleontological data will be involved into the correlation, and regional trends will be better understood. Sedimentological and palaeontological data from the PAET cores will be fed back into the biostratigraphic system, and further palaeontological investigation of the PAET cores holds an opportunity to clarify the temporal extent and chronostratigraphic value of individual species and biozones. Stable isotopic analysis of fossil shells is also in progress; we want to better understand the depositional environments and their temporal changes in Lake Pannon. Mapping of the shelf-margin clinoforms on seismic profiles and cubes as well as the calculation of palaeo-waterdepth based on clinoform height also serves this purpose.

The PAET cores with their fossils and with the seismic network that connects them provide an unprecedented insight into the sedimentological and evolutionary history of Lake Pannon during the latest Miocene.

\section{Acknowledgements}

The investigated cores are property of Paks II Nuclear Power Plant Private Limited Company. Their permission for us to stratigraphically study and sample the cores as well as 
to publish this study is acknowledged here. The drilling, handling and storage of the cores was carried out by Mecsekérc Ltd. The authors thank Miklós Ferenc HoRvátH, László Gombor, Gábor Szurkos, Márton Veszely (Paks II), András BARABÁs, József Csicsák, Gábor HÁmos (Mecsekérc), Gyula KonRÁd (University of Pécs), and Attila AszóDI, at that time Government Commissioner in charge of maintaining the performance of the Paks Nuclear Power Plant, for supporting our research. Special thanks go to Attila Pruzsina (Mecsekérc), our amicable host in the Paks core repository. We thank Christiaan van BAAK, Gijs A. van DIJK, and Ymke Z. LATHOUWERS for their contribution to the magnetostratigraphic study of the cores, which was funded by the Netherlands Organization for Scientific Research (NWO) through the VICI grant of Wout KriJgSMAN. Georges Aumaître, Didier Bourlès, Karim Keddadouche are thanked for their valuable assistance during the ${ }^{10} \mathrm{Be}$ measurements performed at the ASTER AMS national facility (CEREGE, Aix en Provence) which is supported by the INSU/CNRS, the ANR through the "Projets thématiques d'excellence" program for the Equipements d'excellence ASTER-CEREGE action, IRD and CEA. The palaeontological investigations were partly supported by the Hantken Foundation. MOL Hungarian Oil and Gas Plc. is thanked for supporting the 2D seismic correlations between the PAET wells. Koppány FöLDVÁRI is gratefully acknowledged for his valuable GIS \& graphical contribution in the completion of maps. Oleg MANDIC and Edit BABINSZKI are thanked for their careful reviews of the original manuscript. The research was financially supported by the Hungarian National Research, Development and Innovation office, NKFIH 116618. This is MTA-MTM-ELTE Paleo contribution No 302.

\section{References - Irodalom}

Arnold, M., Merchel, S., Bourlès, D. L., Braucher, R., Benedetti, L., Finkel, R. C., Aumaître, G., Gottdang, A. \& Klein, M. 2010 : The French accelerator mass spectrometry facility ASTER: improved performance and developments. — Nuclear Instruments and Methods in Physics Research B 268, 1954-1959. https://doi.org/10.1016/j.nimb.2010.02.107

Babinszki, E., Márton, E., Márton, P. \& Kiss, L. F. 2007: Widespread occurrence of greigite in the sediments of Lake Pannon: Implications for environment and magnetostratigraphy. - Palaeogeography, Palaeoclimatology, Palaeoecology 252, 626-636. http://dx.doi.org/10.1016/j.palaeo.2007.06.001

Balázs, A., Matenco, L., Magyar, I., Horváth, F. \& Cloetingh, S. 2016: The link between tectonics and sedimentation in back-arc basins: New genetic constraints from the analysis of the Pannonian Basin. — Tectonics 35, 1526-1559. https://doi.org/10.1002/ $2015 \mathrm{tc} 004109$

BALÁZs, E. \& Nusszer, A. 1987: Unterpannonischer Vulkanismus der Beckengebiete Ungarns. — Annals of the Hungarian Geological Institute 69, 95-113.

BÉRCZI, I. 1988: Preliminary sedimentological investigation of a Neogene depression in the Great Hungarian Plain. — In: RoYDEN, L. \& Horváth, F. (eds): The Pannonian Basin: A Study in Basin Evolution. American Association of Petroleum Geologists Memoir 45, Tulsa, 107-116.

Bourlès, D. L., Raisbeck, G. M. \& Yiou, F. 1989: ${ }^{10} \mathrm{Be}$ and ${ }^{9} \mathrm{Be}$ in marine sediments and their potential for dating. - Geochimica et Cosmochimica Acta 53, 443-452. https://doi.org/10.1016/0016-7037(89)90395-5

Chmeleff, J., von Blanckenburg, F., Kossert, K. \& JAKob, D. 2010: Determination of the ${ }^{10}$ Be half-life by multicollector ICP-MS and liquid scintillation counting. - Nuclear Instruments and Methods in Physics Research, Section B: Beam Interactions with Materials and Atoms 268, 192-199. https://doi.org/10.1016/j.nimb.2009.09.012

Elston, D. P., LANTOS, M. \& HÁMOR, T. 1994: High resolution polarity records and the stratigraphic and magnetostratigraphic correlation of Late Miocene and Pliocene (Pannonian s.1.) deposits of Hungary. — In: TeleKI, P. G., MATTICK, R. E. \& KóKAI, J. (eds): Basin analysis in petroleum exploration. A case study from the Békés basin, Hungary. Kluwer Academic Publishers, Dordrecht, 111142. https://doi.org/10.1007/978-94-011-0954-3_6

Ganić, M., Rundic, L., KnežEvić, S. \& Cvetrov, V. 2010: The Upper Miocene Lake Pannon marl from the Filijala Open Pit (Beočin, northern Serbia): new geological and paleomagnetic data. — Annales Géologiques de la Péninsule Balkanique 71, 95-108. https://doi.org/10.2298/gabp1071095g

Geary, D. H., Hunt, G., Magyar, I. \& Schreiber, H. 2010: The paradox of gradualism: phyletic evolution in two lineages of lymnocardiid bivalves (Lake Pannon, central Europe). — Paleobiology 36, 592-614. https://doi.org/10.1666/08065.1

Gong, Ch., Sztanó, O., Steel, R. J., Xian, B., Galloway, W. E. \& Bada, G. 2018: Critical differences in sediment delivery and partitioning between marine and lacustrine basins: A comparison of marine and lacustrine aggradational to progradational clinothem pairs. — GSA Bulletin 131, 766-781. https://doi.org/10.1130/b32042.1

Halmai, J., Jámbor, Á., Ravasz-Baranyai, L. \& Vetó, I. 1982: Geological results of the borehole Tengelic-2. — Annals of the Hungarian Geological Institute 65, 11-113.

Hilgen, F. J., Lourens, L. J. \& Van Dam, J. A. 2012: The Neogene Period. — In: Gradstein, F. M., OGG, J. G., Schmitz, M. D. \& OGG, G. M. (eds): The Geologic Time Scale 2012. Elsevier, 923-978. https://doi.org/10.1016/b978-0-444-59425-9.00029-9

HoRváth, F. \& PogÁCSÁs, Gy. 1988: Contribution of seismic reflection data to chronostratigraphy of the Pannonian basin. — In: RoYdEN, L. \& Horváth, F. (eds): The Pannonian Basin: A Study in Basin Evolution. American Association of Petroleum Geologists Memoir 45, Tulsa, 97-105. 
Horváth, F., Koroknai, B., Tóth, T., Wórum, G., Konrád, Gy., Kádi, Z., Kudó, I., HÁmori, Z., Filipszki, P., NémEth, V., SzÁntó, É., Bíró, A., KoroknaI, Zs., Földvári, K. \& KovÁcs, G. 2019: A „Kapos-vonal” középső szakaszának szerkezeti-mélyföldtani viszonyai és neotektonikai jellegei a legújabb geofizikai vizsgálatok tükrében. — Földtani Közlöny, this volume.

JÁmbor, Á., Korpás-Hódi, M., SzÉLES, M. \& SÜTŐ-SzEnTAI, M. 1985: Zentrales Mittleres Donaubecken: Bohrung Lajoskomárom Lk1, S-Balaton. - In: PAPP, A., JÁMBOR, Á. \& STEInINGER, F. F. (eds): Chronostratigraphie und Neostratotypen. Miozän der Zentralen Paratethys VII, M6, Pannonien. Akadémiai Kiadó, Budapest, 204-241.

Juhász, E., Müller, P., Ricketts, B. D., Tóth-Makk, Á., Hámor, T., Farkas-Bulla, J. \& Sütő-Szentai, M. 1996: High-resolution sequence stratigraphy and subsidence analysis of the Late Neogene in the Pannonian Basin, Hungary. Acta Geologica Hungarica 39, $129-152$.

Juhász, E., Ó. Kovács, L., Müller, P., Tóth-Makk, Á., PhilliPs, L. \& LANTOS, M. 1997: Climatically driven sedimentary cycles in the Late Miocene sediments of the Pannonian Basin, Hungary. — Tectonophysics 282, 257-276. http://doi.org/10.1016/S0040-1951(97)00222-9

JuHÁsz, Gy. 1992: Pannonian s.l. formations in the Hungarian Plain: distribution, facies and sedimentary environment. — Földtani Közlöny 122, 133-165.

JuHÁsz, Gy. 1994: Comparison of the sedimentary sequences in Late Neogene subbasins in the Pannonian Basin, Hungary. — Földtani Közlöny 124, 341-365.

Kelder, N. A., Sant, K., Dekkers, M. J., Magyar, I., Van Dijk, G. A., Lathouwers, Y. Z., Sztanó, O. \& Krijgsman, W. 2018 : Paleomagnetism in Lake Pannon; Problems, pitfalls and progress in using iron sulfides for magnetostratigraphy. — Geochemistry, Geophysics, Geosystems 19, 3405-3429. https://doi.org/10.1029/2018GC007673

KoRPÁs-HódI, M. 1982: Pannonian mollusca fauna from the borehole Tengelic 2. - Annals of the Hungarian Geological Institute 65 , 291-306.

Korpás-HódI, M. 1992: The Pannonian (s.1.) molluscs of borehole section Szombathely II. — Annual Report of the Hungarian Geological Institute of 1990, 505-525.

Korschinek, G., Bergmaier, A., Faestermann, T., Gerstmann, U. C., Knie, K., Rugel, G., Wallner, A., Dillmann, I., Dollinger, G., Lierse von Gosstomski, C., Kossert, K., Maiti, M., Poutivtsev, M. \& Remmert, A. 2010: A new value for the ${ }^{10}$ Be half-life by heavy ion elastic recoil detection and liquid scintillation counting. - Nuclear Instruments and Methods in Physics Research Section B: Beam Interactions with Materials and Atoms 268, 187-191. https://doi.org/10.1016/j.nimb.2009.09.020

Krstić, N. 1985: Ostracoden im Pannonien der Umgebung von Belgrad. — In: PAPP, A., JÁMBor, Á. \& Steininger, F. F. (eds): Chronostratigraphie und Neostratotypen. Mioz n der Zentralen Paratethys VII, M6, Pannonien. Akadémiai Kiadó, Budapest, $103-144$.

Lantos, M., Hámor, T. \& Pogácsás, Gy. 1992: Magneto- and seismostratigraphic correlations of Pannonian s.l. (Late Miocene and Pliocene) deposits in Hungary. - Paleontologia i Evolució 24-25, 35-46.

Lebatard, A.-E., Bourlès, D. L., Duringer, Ph., Jolivet, M., Braucher, R., Carcaillet, J., Schuster, M., Arnaud, N., Monié, P., Lihoreau, F., Likius, A., Mackaye, H. T., Vignaud, P. \& Brunet, M. 2008: Cosmogenic nuclide dating of Sahelanthropus tchadensis and Australopithecus bahrelghazali: Mio-Pliocene hominids from Chad. — Proceedings of the National Academy of Sciences 105, 3226-3231. https://doi.org/10.1073/pnas.0708015105

Lemberkovics, V., Kissné Pável, E., Badics, B., Lőrincz, K., Rodionov, A. \& Galimullin, I. 2017: Petroleum system of Miocene troughs of the Pannonian Basin in southern Hungary, based on 3D basin modelling. — Interpretation 6, SB37-SB50. https://doi.org/ 10.1190/int-2017-0075.1

MAGYAR, I. \& SzTANÓ, O. 2008: Is there a Messinian unconformity in the Central Paratethys? — Stratigraphy 5, 247-257.

MagYar, I. \& GeARY, D. H. 2012: Biostratigraphy in a Late Neogene Caspian-type lacustrine basin: Lake Pannon, Hungary. — In: Baganz, O. W., Bartov, Y., Bohacs, K. \& Nummedal, D. (eds): Lacustrine sandstone reservoirs and hydrocarbon systems. American Association of Petroleum Geologists Memoir 95, 255-264.

Magyar, I., Geary, D. H., LANTos, M., MüLleR, P. \& SÜTő-SzEnTAI, M. 1999: Integrated biostratigraphic, magnetostratigraphic and chronostratigraphic correlations of the Late Miocene Lake Pannon deposits. - Acta Geologica Hungarica 42, 5-31.

MagYar, I., LANTOS, M., UjsZÁszi, K. \& Kordos, L. 2007: Magnetostratigraphic, seismic and biostratigraphic correlations of the Upper Miocene sediments in the northwestern Pannonian Basin System. — Geologica Carpathica 58, 277-290.

Magyar, I., Radivojević, D., Sztanó, O., Synak, R., Ujszászi, K. \& Pócsik, M. 2013: Progradation of the paleo-Danube shelf margin across the Pannonian Basin during the Late Miocene and Early Pliocene. - Global and Planetary Change 103, 168-173. https://doi.org/10.1016/j.gloplacha.2012.06.007

MüLleR, P. \& MAGYAR, I. 1992: Continuous record of the evolution of lacustrine cardiid bivalves in the late Miocene Pannonian Lake. — Acta Palaeontologica Polonica 36, 353-372.

PogÁcsás, Gy., LAKATOS, L., RÉVÉSZ, I., UjSZÁsZi, K., VAKARCS, G., VÁRKONYI, L. \& VÁRnAi, P. 1988: Seismic facies, electro facies and Neogene sequence chronology of the Pannonian Basin. — Acta Geologica Hungarica 31, 175-207.

Pogácsás, G., Mattick, R. E., Elston, D. P., Hámor, T., JÁmbor, Á., Lakatos, L., Lantos, M., Simon, E., Vakarcs, G., VÁrkonyi, L. \& VÁrnAI, P. 1994: Correlation of seismo- and magnetostratigraphy in southeastern Hungary. — In: TELEKI, P. G., MATTICK, R. E. \& KóKAI, J. (eds): Basin analysis in petroleum exploration. A case study from the Békés basin, Hungary. Kluwer Academic Publishers, Dordrecht, 143-160. https://doi.org/10.1007/978-94-011-0954-3_7

Raisbeck, G. M., Yiou, F., Fruneau, M., Loiseaux, J. M., Lievin, M. \& Ravel, J. C. 1981: Cosmogenic ${ }^{10}$ Be/ $/{ }^{7}$ Be as a probe of atmospheric transport processes. — Geophysical Research Letters 8, 1015-1018. https://doi.org/10.1029/g1008i009p01015

SACCHI, M. \& MÜLLER, P. 2004: Orbital cyclicity and astronomical calibration of the Upper Miocene continental succession cored at the Iharosberény-I well site, western Pannonian basin, Hungary. — In: D’Argenio, B., Fischer, A. G., Premoli Silva, I., Weissert, H. \& FERrerI, V. (eds): Cyclostratigraphy: Approaches and case histories. —SEPM Special Publication 81, 275-294. https://doi.org/ 10.2110/pec.04.81.0275 
SACCHI, M., HoRVÁTH, F. \& MAGYARI, O. 1999: Role of unconformity-bounded units in the stratigraphy of the continental record: a case study from the Late Miocene of the western Pannonian Basin, Hungary. — In: Durand, B., Jolivet, L., Horváth, F. \& SÉrAnNe, M. (eds): The Mediterranean basins: Tertiary extension within the Alpine orogen. Geological Society, London, Special Publications 156, 357-390. https://doi.org/10.1144/gsl.sp.1999.156.01.17

Šujan, M., Braucher, R., Kováč, M., Bourlès, D. L., Rybár, S., Guillou, V. \& HudéčKová N. 2016: Application of the authigenic ${ }^{10} \mathrm{Be} /{ }^{9} \mathrm{Be}$ dating method to Late Miocene-Pliocene sequences in the northern Danube Basin (Pannonian Basin System): Confirmation of heterochronous evolution of sedimentary environments. — Global and Planetary Change 137, 35-53. https://doi.org/10.1016/ j.gloplacha.2015.12.013

Šujan, M., Braucher, R. \& Aster Team 2018: A test of reproducibility of authigenic beryllium extraction from clay sediment in the facility of the Dept. of Geology and Palaeontology, Comenius University in Bratislava (Slovakia). — Acta Geologica Slovaca 10, 165-169.

SüTŐ-SzENTAI, M. 1982: Organic microplanktonic and sporomorphous remains from the Pannonian from the borehole Tengelic-2. — Annals of the Hungarian Geological Institute 65, 203-233.

SüTő-SzENTAI, M. 2000: Organic walled microplankton zonation of the Pannonian s.l. in the surroundings of Kaskantyú, Paks and Tengelic (Hungary). — Annual Report of the Geological Institute of Hungary of 1994-1995, 153-175.

SzÉLES, M. 1982: Pannonian Ostracoda fauna from the borehole Tengelic 2. — Annals of the Hungarian Geological Institute 65, 235289.

Sztanó, O., Magyar, I., Szónoky, M., Lantos, M., Müller, P., Lenkey, L., Katona, L. \& Csillag, G. 2013a: Tihany Formation in the surroundings of Lake Balaton: type locality, depositional setting and stratigraphy. — Földtani Közlöny 143, 73-98.

Sztanó, O., Szafián, P., Magyar, I., Horányi, A., BadA, G., Hughes D. W., Hoyer, D. L. \& Wallis, R. J. 2013b: Aggradation and progradation controlled clinothems and deep-water sand delivery model in the Neogene Lake Pannon, Makó Trough, Pannonian Basin, SE Hungary. — Global and Planetary Change 103, 149-167. https://doi.org/10.1016/j.gloplacha.2012.05.026

Sztanó, O., Sebe, K., Csillag, G. \& Magyar, I. 2015: Turbidites as indicators of paleotopography, Upper Miocene Lake Pannon, Western Mecsek Mountains (Hungary). — Geologica Carpathica 66, 331-344.

Szuromi-Korecz, A. 1992: A Délkelet-Dunántúl pannóniai s.l. képződményeinek rétegtani értékelése ostracoda faunájuk alapján. — Öslénytani Viták 38, 5-20.

Tóтн-MaKк, Á. 2007: Late Miocene sequence stratigraphy of the Pannonian Basin fill (Kiskunhalas-Mélykút region, Hungary): how core, electric log and seismic data fit together? _ Geologica Carpathica 58, 353-366.

TÖRŐ, B., SzTANÓ, O. \& FodOR, L. 2012: Inherited and syndepositional structural control on the evolution of the slope of Lake Pannon, Northern Somogy, Hungary. — Földtani Közlöny 142, 339-356.

UHRIN, A. \& SzTANÓ, O. 2012: Water-level changes and their effect on deepwater sand accumulation in a lacustrine system: a case study from the Late Miocene of western Pannonian Basin, Hungary. — International Journal of Earth Sciences 101, 1427-1440. https://link.springer.com/article/10.1007/s00531-011-0741-4

Vakarcs, G., Vail, P. R., Tari, G., Pogácsás, G., Mattick, R. E. \& Szabó, A. 1994: Third-order Middle Miocene-Early Pliocene depositional sequences in the prograding delta complex of the Pannonian Basin. — Tectonophysics 240, 81-106. https://doi.org/ 10.1016/0040-1951(94)90265-8

Vasiliev, I., Bakrač, K., Kovačić, M., Abdul AzIz, H. \& Krijgsman, W. 2007: Palaeomagnetic results from the Sarmatian/Pannonian boundary in north-eastern Croatia (Vranović Section; Našice Quarry). _ Geologia Croatica 60, $151-163$.

Wittmann, H., von Blanckenburg, F., Bouchez, J., Dannhaus, N., Naumann, R., Christl, M. \& Gaillardet, J. 2012: The dependence of meteoric ${ }^{10} \mathrm{Be}$ concentrations on particle size in Amazon River bed sediment and the extraction of reactive ${ }^{10} \mathrm{Be} /{ }^{9} \mathrm{Be}$ ratios. — Chemical Geology 318-319, 126-138. https://doi.org/10.1016/j.chemgeo.2012.04.031

Wórum G., Bíró A., Kádi Z., Koroknai B., KovÁcs G. \& Visnovitz F. 2015: Értékelő jelentés a 3D szeizmikus kutatás eredményeiről. Paks II telephelyengedélyének megszerzéséhez szükséges földtani kutatás végrehajtása. MÁ/PA2-15-SZ/0801, Mecsekérc Zrt, 48 p.

Manuscript recieved: 11/07/2019 